\title{
MODEL INKUIRI TERBIMBING MENGGUNAKAN LKS BERORIENTASI KETERAMPILAN BERPIKIR KRITIS UNTUK MENINGKATKAN HASIL BELAJAR BIOLOGI PADA MATERI EKOSISTEM
}

\author{
M. Salahudin Al' Ayub ${ }^{1)}$, Raharjo ${ }^{2)}$, Toeti Koestiari ${ }^{3)}$ \\ ${ }^{1)}$ Mahasiswa Program Studi Pendidikan Dasar, Program Pascasarjana Universitas Negeri Surabaya \\ ${ }^{2), 3)}$ Dosen Pascasarjana Prodi Pendidikan Sains Univesrtitas Negeri Surabaya \\ E-mail: alayub07@gmail.com
}

\begin{abstract}
The aimed of this research to describe the student learning outcomes and critical thinking skills through guided inquiry model using student worksheet oriented of critical thinking skills. This Research was conducted on two stages, are development of teaching materials using Dick and Carey model, and the implementation stage into the classroom using one group pretestposttest design with subjects were 30 students on X class of SMAN 1 Pasir Belengkong Kabupaten Paser Kalimantan Timur. The parameter is feasibility of lesson plan, student activity, learning outcomes, critical thinking skills and constraints for teaching and learning activities. Data collecting were using observation method, test, and questionnaire. After the data were analiyzed with this result: The feasibility of lesson plan could be categorized as good, student activity with instrument reliability classified as good, learning outcomes test to know mastery of student learning on Ecosystems with the average score as good and gain score high gain, critical thinking test with the average score as good and gain score high gain. Based on this research, it can be concluded that guided inquiry model using student worksheet of critical thinking skills can improve student learning outcomes and critical thinking skills.
\end{abstract}

Keywords: Guided Inquiry Model, Worksheet, Critical Thinking Skills, Learning Outcomes, Ecosystems.

\begin{abstract}
Abstrak: Penelitian ini bertujuan untuk mendeskripsikan hasil belajar siswa dan keterampilan berpikir kritis siswa melalui model inkuiri terbimbing menggunakan LKS berorientasi keterampilan berpikir kritis. Penelitian ini dilaksanakan dalam dua tahap, yaitu tahap pengembangan perangkat yang menggunakan model Dick \& Carey, kemudian dilanjutkan dengan tahap implememtasi model di dalam kelas menggunakan rancangan One group Pretest-Posttest Design dengan subjek penelitian 30 siswa kelas X SMAN 1 Pasir Belengkong Kabupaten Paser Kalimantan Timur. Parameter yang diukur meliputi keterlaksanaan RPP, aktivitas siswa, hasil belajar siswa, keterampilan berpikir kritis siswa, respon siswa dan hambatan selama kegiatan belajar. Pengumpulan data menggunakan metode observasi, tes, dan angket. Selanjutnya data dianalisis secara deskriptif. Hasil penelitian menunjukkan Keterlaksanaan RPP dengan kategori baik, aktivitas siswa, dengan reliabilitas instrumen berkategori baik, ketuntasan belajar siswa pada materi ekosistem dengan nilai rata-rata baik dan gain score rata-rata gain tinggi, ketuntasan keterampilan berpikir kritis dengan rata-rata nilai baik dan gain score rata-rata gain tinggi. Berdasarkan hasil penelitian ini dapat disimpulkan bahwa model inkuiri terbimbing menggunakan LKS berorientasi keterampilan berpikir kritis dapat meningkatkan hasil belajar dan keterampilan berpikir kritis siswa.
\end{abstract}

Kata kunci: Model Inkuiri Terbimbing, LKS, Keterampilan Berpikir Kritis, Hasil Belajar, Ekosistem.

\section{PENDAHULUAN}

Permendiknas No. 65 Tahun 2013 tentang standar proses Pendidikan Dasar dan Menengah telah mengisyaratkan tentang perlunya proses pembelajaran yang dipandu dengan kaidah-kaidah pendekatan scientific approach. Upaya penerapan pendekatan scientific approach dalam proses pembelajaran ini sebagai ciri khas dan menjadi kekuatan tersendiri dari keberadaan kurikulum 2013. Kurikulum 2013 merupakan tindak lanjut dari kurikulum berbasis kompetensi (KBK) yang pernah diujicobakan pada tahun 2004 dengan mencakup kompetensi sikap, pengetahuan, dan keterampilan secara terpadu.
Implementasi kurikulum 2013 diharapkan dapat menghasilkan insan yang produktif, kreatif, dan inovatif (Mulyasa, 2013).

Marzano (1992) mengatakan bahwa dalam pembelajaran siswa harus memiliki sikap dan perilaku belajar yang kondusif serta memanfaatkan keterampilan berpikir, untuk selanjutnya tugas pertama siswa dalam belajar yaitu siswa mengumpulkan dan mengintegrasikan pengetahuan baru dimana siswa harus mengasimilasikan pengetahuan baru dan keahliannya dengan apa yang telah diketahuinya.

Keterampilan berpikir dapat dilatihkan guru kepada siswa melalui skenario pembelajaran tertentu. 
Menurut Slavin (1994) penggunaan model pembelajaran yang tepat akan membantu guru menjalankan tugas profesinya agar tujuan pembelajaran dapat dicapai. Banyak dijumpai bermacam-macam model pembelajaran di dalam proses belajar mengajar, salah satu strategi yang dapat dilakukan guru dalam pembelajaran yaitu dengan menggunakan model pembelajaran inkuri yang sejalan dengan pendekatan scientific approach dalam kurikulum 2013.

Melibatkan siswa di dalam model pembelajaran inkuiri merupakan salah satu cara yang efektif untuk membantu mereka mengembangkan keterampilan berpikir tingkat tinggi dan berpikir kritis. Inkuiri pada dasarnya dapat dipandang sebagai suatu proses untuk menjawab pertanyaan dan memecahkan masalah berdasarkan fakta dan observasi (Kardi, 2013). Berpikir kritis adalah interpretasi dan evaluasi yang terampil dan aktif terhadap observasi dan komunikasi, informasi dan argumentasi (Fisher, 2009). Pengembangan kemampuan berpikir kritis merupakan integrasi beberapa bagian pengembangan kemampuan, seperti pengamatan (observasi), analisis, penalaran, penilaian, dan pengambilan keputusan. Pengembangan kemampuan berpikir kritis ini semakin baik, maka akan semakin dapat mengatasi masalah-masalah kompleks dan dengan hasil yang memuaskan.

Keberhasilan pembelajaran tidak hanya dilihat dari hasil akhir proses kegiatan belajar, tetapi juga harus diperhatikan peningkatan kemampuannya selama proses kegiatan belajar mengajar berlangsung. Seorang guru yang profesional dituntut untuk dapat menguasai dan mengembangkan metode pengajarannya serta faktorfaktor pendukung keberhasilan mengajar yang ada di dalam kelas. Salah satu cara yang banyak ditempuh oleh guru dalam mengaktifkan siswa adalah dengan menggunakan Lembar Kegiatan Siswa (LKS). Hampir setiap guru diberbagai sekolah menggunakan LKS sebagai sarana atau acuan untuk memandu pelaksanaan kegiatan belajar mengajar, terutama praktikum.

Permasalahan dalam kegiatan belajar mengajar juga dialami di SMA Negeri 1 Pasir Belengkong diantaranya pola pembelajaran biologi yang masih bersifat terpusat pada guru (teacher centered) ternyata masih sering dilakukan, keterampilan dan kemampuan berpikir kritis pada siswa belum dilatihkan dan dikembangkan secara maksimal. Guru hanya menekankan pada penghafalan konsep-konsep yang mengutamakan produk daripada prosesnya, sebagian besar penyampaian materi pelajaran hanya menggunakan ceramah hal ini menyebabkan siswa menjadi jenuh dan bosan sehingga berdampak pada hasil belajar siswa yang masih rendah selain itu pada umumnya LKS yang digunakan guru adalah LKS yang kurang sesuai dengan situasi dan kondisi siswa.
Nur (1995) mengungkapkan bahwa secara terus menerus sampai saat ini, di SMP dan SMA sedang terjadi pengajaran IPA yang terbatas pada produk, konsep, dan teori saja. Sejalan dengan itu, Kasnan (2001) mengemukakan bahwa proses pembelajaran biologi masih berfokus hanya pada penguasaan materi biologi oleh siswa, sedangkan penguasaan sikap dan keterampilan dalam belajar belum mendapat perhatian yang memadai. Biologi selain mengkaji pengetahuan tentang makhluk hidup, juga usaha untuk menumbuhkan dan mengembangkan sikap, keterampilan berpikir serta meningkatkan keterampilan untuk menjalankan penelitian dalam bidang biologi melalui langkah-langkah ilmiah. Materi biologi secara umum merupakan materi yang bersifat fakta dan ada di alam semesta sehingga sangat memungkinkan untuk ditelaah lebih jauh. Mempelajari alam sebagai sistem ekologi atau alam merupakan suatu ekosistem yang sangat luas.

Ekosistem merupakan salah satu materi yang disediakan oleh alam. Materi ekosistem secara umum sudah disampaikan sejak SMP, tetapi penyampaian yang dilakukan lebih banyak bersifat hafalan dan kurangnya mengembangkan proses berpikir. Materi ekosistem sangat memungkinkan untuk dijadikan materi yang perlu dikembangkan dengan pembelajaran model inkuiri terbimbing menggunakan LKS berorientasi keterampilan berpikir kritis karena dapat melatih kemampuan berpikir kritis dan dapat meningkatkan hasil belajar. Pembelajaran model inkuiri adalah salah satu model pembelajaran yang biasa dipilih oleh guru dalam pembelajaran di kelas. Model pembelajaran mengandung tujuan, sintaks, lingkungan, dan sistem manajemen. Model inkuiri adalah desain khusus untuk membimbing siswa bagaimana meneliti masalah dan pertanyaan berdasarkan fakta (Kardi, 2013).

Menurut Trianto (2007) pembelajaran inkuiri terbimbing dilaksanakan melalui tahapan-tahapan sebagai berikut: (1) Menyajikan pertanyaan atau permasalahan, (2) membuat hipotesis, (3) merancang percobaan, (4) Melakukan percobaan untuk memperoleh informasi, (5) mengumpulkan dan menganalisis data, dan (6) membuat kesimpulan. Berdasarkan uraian diatas maka penelitian ini bertujuan untuk mendeskripsikan hasil belajar siswa setelah dilakukan pembelajaran model inkuiri terbimbing menggunakan LKS berorientasi keterampilan berpikir kritis pada materi ekosistem.

\section{METODE PENELITIAN}

Penelitian yang dilaksanakan ini merupakan penelitian penerapan perangkat pembelajaran pada siswa (pra eksperimen). Sebelum melakukan penelitian 
ini, terlebih dahulu dilakukan pengembangan perangkat pembelajaran yang akan digunakan. Subjek penelitian adalah siswa SMA Negeri 1 Pasir Belengkong kelas X semester ganjil tahun pelajaran 2014/2015 sebanyak 30 siswa. Penelitian ini menggunakan model One Group Pretest-Postest Design (Tuckman, 1978). Desain penelitian ini dapat digambarkan sebagai berikut:

Tabel 1. Desain penelitian

\begin{tabular}{|c|c|c|}
\hline Uji Awal & Perlakuan & Uji Akhir \\
\hline $\mathrm{O}_{1}$ & $\mathrm{X}$ & $\mathrm{O}_{2}$ \\
\hline
\end{tabular}

Keterangan:

$=$ Uji awal, untuk mengetahui tingkat

$\mathrm{O}_{1} \quad$ penguasaan siswa terhadap materi pembelajaran sebelum diberikan pembelajaran model inkuiri terbimbing menggunakan LKS berorientasi keterampilan berpikir kritis

$\mathrm{X}=$ Memberikan perlakuan pada siswa, yaitu dengan memberikan pembelajaran model inkuiri terbimbing menggunakan LKS berorientasi keterampilan berpikir kritis

$\mathrm{O}_{2}=$ Uji akhir, untuk mengetahui hasil belajar dan tingkat penguasaan siswa terhadap materi pembelajaran setelah diberikan pembelajaran model inkuiri terbimbing menggunakan LKS berorientasi keterampilan berpikir kritis
Penelitian ini terdiri dari 2 tahap. Tahap persiapan, yaitu tahap pengembangan perangkat pembelajaran dan tahap implementasi di kelas. Prosedur penelitian menggunakan rancangan pengembangan perangkat pembelajaran model Dick \& Carey yang diikuti dengan uji coba perangkat pembelajaran di kelas.

Model ini dimulai dengan mengidentifikasi tujuan pembelajaran umum. Sebelum merumuskan tujuan performasi (khusus) perlu menganalisis pembelajaran dan identifikasi tingkah laku awal siswa. setelah dirumuskan tujuan khusus yang harus dicapai selanjutnya dirumuskan tes acuan, artinya tes mengukur kemampuan tujuan khusus, untuk mencapai tujuan khusus selanjutnya dikembangkan strategi pembelajaran, yakni skenario pelaksanaan pembelajaran yang diharapkan dapat mencapai tujuan secara optimal, setelah itu dikembangkan perangkat pelajaran yang sesuai dengan tujuan.

Langkah akhir dari desain adalah melakukan evaluasi, yakni evaluasi formatif dan evaluasi sumatif. Evaluasi formatif berfungsi untuk menilai program dan evaluasi sumatif berfungsi untuk menentukan kedudukan setiap siswa dalam penguasaan materi pelajaran. Berdasarkan hasil evaluasi inilah selanjutnya dilakukan umpan balik dalam merevisi program pembelajaran. Model pembelajaran Dick and Carey dinyatakan pada Gambar berikut.

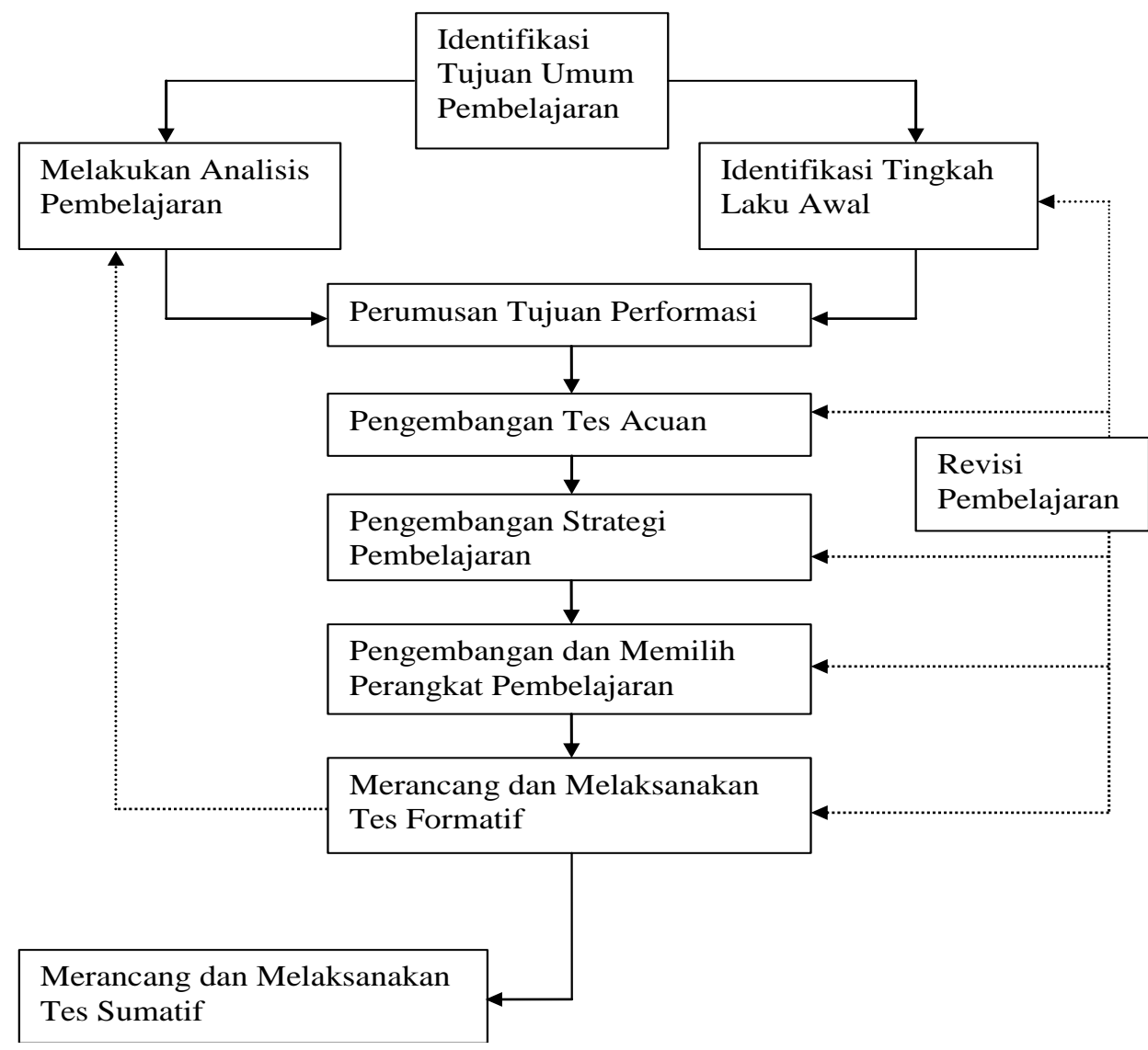

Gambar 1. Diagram Pengembangan Perangkat Model Dick \& Carey. Sumber: (Dick \& Carey, 1990) 
Penelitian ini menggunakan beberapa teknik pengumpulan data, antara lain:

\section{Observasi/pengamatan}

Teknik pengamatan digunakan untuk memperoleh data penelitian tentang keterlaksanaan RPP, aktivitas siswa dan hambatan-hambatan selama kegiatan belajar mengajar berlangsung.

\section{Tes}

Metode tes digunakan untuk memperoleh data penelitian tentang hasil belajar siswa dan keterampilan berpikir kritis siswa. Tes dilakukan sebelum pembelajaran (pretest) dan setelah tiga kali pertemuan pembelajaran (posttes). Waktu untuk mengerjakan pretest/posttest 2 jam pelajaran (90 menit).

\section{Pemberian Angket}

Angket digunakan untuk memperoleh dan mengetahui respon siswa terhadap pembelajaran model inkuiri terbimbing dengan menggunakan LKS berorientasi keterampilan berpikir kritis.

Instrumen dalam penelitian ini meliputi:

\section{Lembar Pengamatan}

a. Lembar Pengamatan Keterlaksanaan RPP

Adalah instrumen berupa tabel dengan kolom yang terdiri dari: aspek yang diamati, keterlaksanaan, dan penilaian. Aspek yang diamati dalam pembelajaran meliputi: pendahuluan, kegiatan inti, penutup, suasana kelas, dan alokasi waktu setiap pertemuan. Keterlaksanaan terdiri dari dua aspek yaitu Ya terlaksana dan Tidak. Aspek penilaian yaitu: sangat baik, baik, cukup baik, kurang baik, dan tidak baik. Instrumen ini berguna untuk melakukan penilaian terhadap kualitas keterlaksanaan RPP yang dilakukan guru selama KBM.

\section{b. Lembar Pengamatan Aktivitas Siswa}

Adalah lembar pengamatan yang digunakan untuk menganalisis aktivitas keterlibatan siswa selama pembelajaran berlangsung dengan melihat persentase aktivitas yang dilakukan siswa selama KBM dibagi keseluruhan aktivitas yang dirancang dikalikan $100 \%$. Aktivitas siswa yang diamati, yaitu memperhatikan atau menanggapi/mendengar penjelasan guru atau teman, membaca materi ajar siswa atau LKS, menanggapi masalah/merumuskan masalah/pertanyaan, merumuskan hipotesis, merancang dan melakukan pengamatan/percobaan, mencatat dan menganalisis hasil pengamatan/percobaan, mempresentasikan hasil pengamatan dan berdiskusi kelas, membuat kesimpulan, bertanya pada guru atau teman, dan perilaku yang tidak relevan dengan KBM.

Kedua instrumen pengamatan di atas masingmasing dipegang oleh dua orang pengamat, sehingga perlu dihitung reliabilitasnya. Perhitungan reliabilitas instrumen dilakukan dengan suatu teknik yang dikemukakan oleh Borich (1994) yaitu teknik interobserver agreement. Menurut teknik ini dua orang pengamat menggunakan instrumen yang sama untuk mengamati variabel yang sama, kemudian hasil pengamatan dihitung dengan menggunakan rumus percentage of agreement sebagai berikut:

$$
\mathrm{R}=\left[1-\frac{\mathrm{A}-\mathrm{B}}{\mathrm{A}+\mathrm{B}}\right] \times 100 \%
$$

Keterangan:

$$
\begin{aligned}
\mathrm{R}= & \text { Koefisien reliabilitas } \\
\mathrm{A}= & \text { Frekuensi aspek tingkah laku yang teramati } \\
& \text { oleh pengamat dengan memberikan frekuensi } \\
& \text { tinggi } \\
\mathrm{B}= & \text { Frekuensi aspek tingkah laku yang teramati } \\
& \text { oleh pengamat dengan memberikan frekuensi } \\
& \text { rendah }
\end{aligned}
$$

Instrumen pengamatan digolongkan baik, bila nilai koefisien reliabilitas yang diperoleh $\geq 75 \%$.

\section{Hasil Belajar Siswa}

a. Tes Hasil Belajar

Tes Hasil Belajar (THB) adalah alat penilaian yang berisikan pertanyaan yang diberikan pada siswa dalam bentuk tes tertulis. Tes ini bertujuan untuk mengukur kemampuan siswa dalam menguasai materi yang diajarkan dan dibuat berdasarkan kisi-kisi penyusunan soal sesuai dengan tujuan pembelajaran yang hendak dicapai. Bentuk instrumen THB berupa soal pilihan ganda dan uraian. Tes pilihan ganda yang digunakan terdiri dari lima pilihan jawaban, sedangkan tes uraian digunakan karena dapat merekam proses berpikir yang menunjukkan tingkat pemahaman yang lebih tinggi seperti kemampuan berpikir kritis. Tes hasil belajar siswa yang digunakan harus mempunyai indeks sensitivitas yang baik. Indeks sensitivitas dari suatu butir soal merupakan ukuran seberapa baik butir soal membedakan antara siswa yang telah menerima pembelajaran dengan siswa yang belum menerima pembelajaran. Menghitung sensitivitas butir soal bentuk pilihan ganda digunakan rumus sebagai berikut: (Gronlund, 1982)

$$
\text { Sensitivitas }=\frac{\mathrm{Ra}-\mathrm{Rb}}{\mathrm{T}}
$$

\section{Keterangan:}

$\mathrm{Ra}=$ Banyak siswa yang menjawab benar pada tes akhir

$\mathrm{Rb}=$ Banyak siswa yang menjawab benar pada tes awal

$\mathrm{T}=$ Banyak siswa yang mengikuti tes

Untuk mengetahui indeks sensitivitas butir soal bentuk soal uraian menggunakan rumus:

$$
\text { Sensitivitas }=\frac{\sum \mathrm{U} 12-\Sigma \mathrm{U} 21}{\mathrm{~N}(\text { Skor } \max -\text { Skor } \min )}
$$




\section{Keterangan:}

$\Sigma \mathrm{U} 21=$ Jumlah skor pretest (sebelum pembelajaran berlangsung).

$\Sigma \mathrm{U} 12=$ Jumlah skor post test (setelah pembelajaran berlangsung).

Skor $\max =$ skor maksimal yang dicapai untuk setiap butir tes.

Skor $\min =$ skor minimum yang dicapai untuk setiap butir tes

$\mathrm{N} \quad=$ banyaknya siswa yang mengikuti tes

Menurut Gronlund (1982), butir soal dikatakan sensitif apabila sensitivitas butir soal berharga 0,30 sampai dengan 1,00. Nilai positif semakin besar menunjukkan bahwa kepekaan butir soal terhadap efekefek pembelajaran juga semakin besar. Ketuntasan hasil belajar siswa ditentukan dari: ketuntasan indikator, ketuntasan individual, dan klasikal. Suatu indikator dikatakan tuntas apabila $\geq 75 \%$ siswa mencapai indikator. Kriteria Ketuntasan Minimal (KKM) mata pelajaran biologi kelas X di SMAN 1 Pasir Belengkong dikategorikan tuntas jika nilai yang diperoleh sebesar 70 atau dikonversi sebesar $\geq 2,80$. Pembelajaran secara klasikal dikatakan tuntas apabila $\geq 75 \%$ individu tuntas.

\section{b. Lembar Penilaian Keterampilan}

Adalah alat penilaian yang berisikan aspek-aspek yang dinilai meliputi melakukan penyelidikan terdiri dari merumuskan masalah, merumuskan hipotesis, merencanakan prosedur percobaan, melakukan pengamatan, melakukan analisis data dan menyimpulkan, mengomunikasikan hasil penyelidikan terdiri dari penguasaan konsep, penampilan presenter, dan tayangan presenter. Penilaian pencapaian kompetensi keterampilan merupakan penilaian yang dilakukan terhadap siswa untuk menilai sejauh mana pencapaian kompetensi khususnya dalam dimensi keterampilan.

\section{c. Lembar Penilaian Sikap}

Adalah alat penilaian yang berisikan karakter sikap siswa yang diwujudkan dalam perilaku sebagai bagian dari pembelajaran. Karakter sikap siswa meliputi kompetensi sikap spiritual (KI-1) yang terkait dengan pembentukan siswa yang beriman dan bertakwa, sikap sosial (KI-2) yang meliputi sikap disiplin dan rasa ingin tahu. Penilaian sikap bersumber dari hasil penilaian teknik observasi dan penilaian diri dengan daftar cek atau skala penilaian yang disertai rubrik

\section{Tes Keterampilan Berpikir Kritis}

Adalah instrumen berupa alat penilaian yang berisikan pertanyaan yang diberikan pada siswa dalam bentuk tes tertulis. Tes ini bertujuan untuk mengetahui dan mengukur kemampuan berpikir kritis siswa dalam menguasai materi yang diajarkan dengan menggunakan LKS berorientasi keterampilan berpikir kritis. Bentuk tes keterampilan berpikir kritis berupa soal uraian sebanyak 5 soal yang terdiri dari indikator berpikir kritis meliputi merumuskan masalah, memberi argumen (hipotesis), melakukan analisis, menyimpulkan dan mengevaluasi.

\section{Angket Respon Siswa}

Adalah instrumen berupa angket yang diberikan kepada siswa pada akhir penelitian. Bentuk instrumen berupa Tabel dengan kolom yang terdiri dari: uraian pertanyaan dan penilaian/pendapat dimana jawabannya telah ditentukan, siswa tinggal memilih jawaban yang diinginkan. Angket ini dikembangkan dengan tujuan memperoleh data mengenai respon siswa terhadap perangkat pembelajaran, proses pembelajaran, dan keterampilan berpikir kritis siswa yang dilatihkan.

\section{Lembar Observasi Hambatan}

Adalah instrumen pengamatan hambatan selama kegiatan pembelajaran. Bentuk instrumen berupa Tabel dengan kolom yang terdiri dari: jenis hambatan dan solusi alternatif. Tujuan penggunaan instrumen ini untuk mengetahui hambatan yang muncul di lapangan selama pembelajaran. Observasi kendala lapangan dilakukan dua pengamat sedangkan solusinya didiskusikan antara pengamat dan yang meneliti.

Teknik analisis data dalam penelitian ini dilakukan dengan menggunakan analisis deskriptif yang meliputi:

\section{Analisis Kelayakan Perangkat Pembelajaran}

Perangkat RPP, Materi Ajar Siswa, dan LKS yang dikembangkan selanjutnya dilakukan telaah oleh validator. Data hasil penilaian dianalisis secara deskriptif kualitatif. Rata-rata hasil penilaian oleh validator merupakan kelayakan perangkat yang telah dikembangkan. Dalam penelitian ini batas penerimaan adalah skor rerata $(\mathrm{X})$ dari hasil penilaian kemudian ditentukan tingkat kelayakan perangkat yang dikembangkan dengan mencocokan kriteria penilaian perangkat pembelajaran sebagai berikut:

Tabel 2. Kriteria Penilaian RPP, Materi Ajar, dan LKS.

\begin{tabular}{|c|c|}
\hline Interval Skor & Kategori Penilaian \\
\hline $4,01 \leq \mathrm{P}<5,00$ & Sangat Baik \\
\hline $3,01 \leq \mathrm{P}<4,00$ & Baik \\
\hline $2,01 \leq \mathrm{P}<3,00$ & Cukup Baik \\
\hline $1,00 \leq \mathrm{P}<2,00$ & Kurang Baik \\
\hline
\end{tabular}

(Diadaptasi dari Khabibah, 2006)

Perhitungan reliabilitas instrumen penilaian perangkat pembelajaran menggunakan rumus sebagai berikut. (Watkins, 2001)

$$
\mathrm{R}=\frac{\mathrm{A}}{\mathrm{D}+\mathrm{A}} \times 100 \%
$$


Keterangan:

$$
\begin{aligned}
& \mathrm{R}=\begin{array}{l}
\text { Reliabilitas Instrumen (percentage of } \\
\text { Agreement) }
\end{array} \\
& \mathrm{A}=\begin{array}{l}
\text { Frekuensi kecocokan antara kedua pengamat } \\
\text { (Agree) }
\end{array} \\
& \mathrm{D}=\begin{array}{l}
\text { Frekuensi ketidakcocokan antara kedua } \\
\text { pengamat (Disagree) }
\end{array}
\end{aligned}
$$

Instrumen penilaian perangkat pembelajaran dikatakan reliabel, jika nilai reliabilitasnya $\geq 75 \%$ (Borich, 1994).

\section{Analisis Hasil Pengamatan Keterlaksanaan Pembelajaran}

Pengamatan keterlaksanaan RPP dilakukan oleh dua orang pengamat yang sudah dilatih memberikan penilaian pada instrumen. Aspek yang diamati meliputi: pendahuluan, kegiatan inti, penutup, suasana kelas, dan alokasi waktu. Kriteria setiap fase pembelajaran dinilai dengan memberikan tanda checklist $(\sqrt{ })$ pada kolom keterlaksanaan (ya atau tidak) dan pada kolom penilaian (5: Sangat Baik, 4: Baik, 3: Cukup Baik, 2: Kurang Baik, 1: Tidak Baik). Data hasil pengamatan dianalisis secara deskriptif kuantitatif dengan membandingkan rata-rata skala penilaian yang diberikan oleh kedua pengamat dengan kriteria penilaian sebagai berikut:

Tabel 3. Kriteria penilaian keterlaksanaan pembelajaran

$1,00 \leq X \leq 1,49$ berarti tidak baik (tidak dilakukan

$50<\mathrm{X}<2,49$ berarti kurang baik (dilakukan

$\leq \quad$ tetapi tidak selesai)

$50 \leq X \leq 3,49 \quad$ berarti cukup baik (dilakukan tetapi

$50 \leq X<4,49 \quad$ berarti baik (dilakukan dengan tepat

tetapi tidak sesuai dengan waktu)

$50 \leq X \leq 5,00 \quad$ berarti sangat baik (dilakukan dengan tepat )

(Kardi, 2002)

\section{Analisis Aktivitas Siswa}

Aktivitas siswa adalah segala aktivitas yang dilakukan siswa selama KBM berlangsung dan dinilai oleh dua orang pengamat. Data yang diperoleh selanjutnya dianalisis deskriptif kualitatif. Rumus yang digunakan adalah jumlah frekuensi tiap aktivitas siswa yang muncul dibagi jumlah total frekuensi aktivitas dikali $100 \%$. Data aktivitas siswa yang diperoleh selanjutnya dimasukkan dalam Tabel.

\section{Analisis Tes Hasil Belajar}

a. Analisis hasil belajar pengetahuan

Data tes hasil belajar pengetahuan di analisis secara deskriptif, yakni dengan menggunakan ketuntasan siswa. Analisis ketuntasan belajar siswa menggunakan kriteria acuan patokan. Menurut Lampiran IV Permendikbud No 81A Tahun2013 ketuntasan belajar ditentukan sebagai berikut:
Tabel 4. Konversi Kompetensi Pengetahuan, Keterampilan, dan Sikap

\begin{tabular}{|c|c|c|l|}
\hline \multirow{2}{*}{ Predikat } & \multicolumn{3}{|c|}{ Nilai Kompetensi } \\
\cline { 2 - 3 } & Pengetahuan & Keterampilan & \multirow{2}{*}{ Sikap } \\
\hline A & 4 & 4 & \multirow{2}{*}{ SB } \\
\hline A- & 3,66 & 3,66 & \\
\hline B+ & 3,33 & 3,33 & \multirow{2}{*}{ B } \\
\hline B & 3 & 3 & \\
\hline B- & 2,66 & 2,66 & \\
\hline C+ & 2,33 & 2,33 & \multirow{2}{*}{ C } \\
\hline C & 2 & 2 & \\
\hline C- & 1,66 & 1,66 & \\
\hline D+ & 1,33 & 1,33 & \multirow{2}{*}{ K } \\
\hline D & 1 & 1 & \\
\hline
\end{tabular}

(Sumber: Kemendikbud, 2013)

Konversi nilai yang dilakukan meliputi nilai pada pengetahuan, keterampilan dan sikap. Cara konversi skor ke skala $1-4$ adalah sebagai berikut:

$$
\frac{\text { Skor diperoleh }}{\text { Skor maksimal }} \times 4=\text { skor akhir }
$$

Presentase ketuntasan belajar siswa dihitung dengan rumus berikut :

1) Ketuntasan Indikator

Ketuntasan indikator dihitung dengan menggunakan rumus:

$$
=\frac{\Sigma \text { Siswa yang mencapai indikator }}{\Sigma \text { siswa }} \times 100 \%
$$

ketuntasan indikator pada KI-3 dan KI-4 dikatakan tuntas apabila menunjukkan nilai $\geq 75 \%$ siswa mencapai indikator tersebut.

2) Ketuntasan Individual dan klasikal

Ketuntasan individual dihitung dengan menggunakan rumus:

$\%$ Ketuntasan individual

$$
=\frac{\text { Jumlah butir dengan jawaban benar }}{\text { jumlah seluruh butir soal }} \times 100 \%
$$

Komptensi dasar pada KI-3 dan KI-4 siswa dikatakan tuntas secara individual apabila menunjukan indikator nilai $\geq 2.80$ dengan predikat $\mathrm{B}$-.

Ketuntasan klasikal dihitung dengan menggunakan rumus:

$$
\begin{aligned}
& \% \text { Ketuntasan klasikal } \\
& =\frac{\text { Jumlah siswa yang tuntas }}{\text { jumlah seluruh siswa }} \times 100 \%
\end{aligned}
$$

Komptensi dasar pada KI-3 dan KI-4 siswa dikatakan tuntas secara klasikal apabila menunjukan indikator nilai $\geq 75 \%$ siswa memperoleh nilai $\geq 2.80$ dengan predikat $\mathrm{B}^{-}$

Data hasil belajar pengetahuan siswa yang diperoleh, selanjutnya dianalisis menggunakan gain-score (peningkatan skor) antara pretes dan posttes. Besarnya peningkatan atau gain-score dianalisis menggunakan rumus Hake (1999) :

$$
\mathrm{g}=\frac{S_{\text {post }}-S_{\text {pre }}}{100 \%-S_{\text {pre }}}
$$




\section{Keterangan:}

$\mathrm{g}($ gain $)=$ Peningkatan peguasaan pengetahuan

$S_{\text {pre }}=$ rata-rata pre-tes atau kemampuan awal $(\%)$

$\mathrm{S}_{\text {post }}=$ rata-rata post-tes atau kemampuan akhir $(\%)$

Savinainen \& Scott (2002) mengklasifikasikan gain sebagai berikut:

$$
\begin{array}{ll}
\text { g- tinggi } & =(\mathrm{g})>0,7 \\
\text { g-sedang } & =0,7>(\mathrm{g})>0,3 \\
\text { g-rendah } & =(\mathrm{g})<0,3
\end{array}
$$

b. Analisis hasil belajar keterampilan

Hasil belajar keterampilan menggunakan lembar observasi. Data hasil belajar keterampilan dianalisis secara deskriptif, untuk Kompetensi Dasar (KD) pada KI-3 dan KI-4 siswa dikatakan tuntas secara individual untuk menguasai KD yang dipelajarinya apabila menunjukan indikator nilai $\geq 2.80$ dengan predikat $\mathrm{B}$ .yakni dengan mengunakan ketuntasan siswa mengacu pada Lampiran Permendikbud No 81A untuk pencapaian kompetensi keterampilan seperti Tabel 2 diatas.

\section{c. Analisis hasil belajar sikap}

Hasil belajar sikap terbagi menjadi dua yaitu hasil belajar sikap spiritual dan hasil belajar sosial. Hasil belajar sikap menggunakan lembar pengamatan observasi siswa dan lembar penilaian diri siswa. Data hasil belajar sikap dianalisis secara deskriptif, yakni dengan mengunakan ketuntasan siswa mengacu pada Lampiran Permendikbud No 81A pencapaian minimal untuk kompetensi sikap adalah baik (B) dengan konversi nilai sebagai berikut:

Sangat Baik: apabila memperoleh skor: $3,33<$ skor $\leq$ 4,00

Baik : apabila memperoleh skor: $2,33<$ skor $\leq 3,33$

Cukup : apabila memperoleh skor: $1,33<$ skor $\leq 2,33$

Kurang : apabila memperoleh skor: skor $\leq 1,33$

\section{Analisis Respon Siswa}

Angket respon siswa digunakan untuk mengetahui pendapat siswa terhadap perangkat pembelajaran yang dikembangkan dan keterampilan berpikir kritis yang dilatihkan, suasana belajar, dan cara guru mengajar. Respon siswa dianalisis secara deskriptif kuantitatif dengan persentase yaitu jumlah respon siswa dibagi junlah keseluruhan respon dikalikan 100\%

Rumus perhitungan respon siswa sebagai berikut:

$$
\mathrm{P}=\frac{\Sigma R}{\Sigma N} \times 100 \%
$$

Keterangan: $\mathrm{P}=$ Persentase

$\Sigma \mathrm{R}=$ Jumlah respon

$\Sigma \mathrm{N}=$ Jumlah keseluruhan respon
6. Analisis hambatan selama Kegiatan Belajar

Mengajar

Menganalisis hambatan selama pelaksanaan pembelajaran dianalisis secara deskriptif kualitatif dengan cara mengumpulkan dan mendiskusikan saransaran yang diberikan pengamat terhadap kegiatan pembelajaran yang telah dilakukan.

\section{HASIL PENELITIAN DAN DISKUSI}

Hasil yang diharapkan dalam penelitian ini adalah tersedianya LKS berorientasi keterampilan berpikir kritis melalui pembelajaran model inkuiri terbimbing untuk melatihkan berpikir kritis siswa pada materi ekosistem sehingga berdampak pada hasil belajar dan menghasilkan sumber daya manusia yang mempunyai kemampuan berpikir logis, kritis, dan inovatif dalam pengambilan keputusan.

Sebelum pembelajaran dilaksanakan, pengembangan perangkat pembelajaran yang telah divalidasi oleh validator berkategori baik, layak digunakan dalam pembelajaran. Hal ini sesuai dengan ketentuan yang menyatakan bahwa perangkat pembelajaran dikatakan sangat baik jika skor hasil penilaian perangkat tersebut berada pada interval $4,01 \leq$ $\mathrm{P} \leq 5,00$ (Khabibah, 2006). Hasil penilaian perangkat tersebut didukung oleh reliabilitas instrumen dengan ketentuan yang menyatakan bahwa suatu penilaian dikatakan reliabel jika memiliki nilai reliabilitas lebih besar atau sama dengan 75\% (Borich, 1994)

Pengamatan meliputi: keterlaksanaan RPP, aktivitas siswa, hasil belajar siswa, respon siswa, dan hambatan. Analisis terhadap hasil penelitian mengunakan deskriptif kualitatif dan deskriptif kuantitatif berupa deskripsi skor rata-rata dan persentase. Hasil yang diperoleh pada tahap implementasi terdiri dari data-data sebagai berikut:

\section{A. Hasil Pengamatan Keterlaksanaan RPP}

Pengamatan keterlaksanaan RPP selama penelitian ini dilakukan setiap kali tatap muka oleh dua pengamat. Keterlaksanaan RPP model inkuiri terbimbing menggunakan LKS berorientasi keterampilan berpikir kritis adalah skor yang diperoleh berdasarkan hasil pengamatan terhadap keterlaksanaan langkah-langkah dalam pelaksanaan pembelajaran. Pengamatan dilakukan dengan menggunakan lembar penilaian keterlaksanaan rencana pelaksanaan pembelajaran Rangkuman hasil pengamatan keterlaksanaan RPP sebagai berikut:

Tabel 5. Hasil Pengamatan Keterlaksanaan RPP

\begin{tabular}{|c|c|c|c|c|c|}
\hline No & Aspek Yang & \multicolumn{4}{|c|}{ Pertemuan 1 } \\
\cline { 3 - 6 } & Diamati & P I & P II & Rerata & Kategori \\
\hline 1 & $\mathbf{2}$ & 3 & 4 & 5 & 6 \\
\hline A & Pendahuluan & 4.3 & 4.6 & 4.44 & Baik \\
\hline
\end{tabular}




\begin{tabular}{|c|c|c|c|c|c|c|c|}
\hline B & Kegiatan Inti & 3.8 & 4.8 & 4.28 & Baik & \multirow{2}{*}{$2,50 \leq X \leq 3,49$} & \multirow{2}{*}{$\begin{array}{l}\text { berarti cukup baik (dilakukan } \\
\text { tetapi kurang tepat) }\end{array}$} \\
\hline $\mathrm{C}$ & Penutup & 4.0 & 4.8 & 4.40 & Baik & & \\
\hline $\mathrm{D}$ & $\begin{array}{l}\text { Suasana } \\
\text { Kelas }\end{array}$ & 4.3 & 4.5 & 4.42 & Baik & \multirow{3}{*}{$\begin{array}{l}3,50 \leq X \leq 4,49 \\
4,50 \leq X \leq \\
5,00\end{array}$} & \multirow{3}{*}{$\begin{array}{l}\text { berarti baik (dilakukan tepat } \\
\text { tetapi tidak sesuai waktu) } \\
\text { berarti sangat baik (dilakukan } \\
\text { dengan tepat) }\end{array}$} \\
\hline $\mathrm{E}$ & $\begin{array}{l}\text { Alokasi } \\
\text { Waktu }\end{array}$ & 3.0 & 3.0 & 3.00 & $\begin{array}{c}\text { Cukup } \\
\text { Baik }\end{array}$ & & \\
\hline \multicolumn{2}{|c|}{ Jumlah Rerata } & 3.87 & 4.34 & 4.11 & Baik & & \\
\hline
\end{tabular}

(Kardi, 2002)

\begin{tabular}{|c|c|c|c|c|c|}
\hline \multirow{2}{*}{\multicolumn{2}{|c|}{$\begin{array}{c}\text { Keterlaksanaan } \\
\text { Reliabilitas }\end{array}$}} & $77 \%$ & $87 \%$ & $82 \%$ & \\
\hline & & \multicolumn{4}{|c|}{$94.30 \%$} \\
\hline \multirow[t]{2}{*}{ No } & \multirow{2}{*}{$\begin{array}{c}\text { Aspek Yang } \\
\text { Diamati }\end{array}$} & \multicolumn{4}{|c|}{ Pertemuan 2} \\
\hline & & P I & P II & Rerata & Kategori \\
\hline 1 & 2 & 3 & 4 & 5 & 6 \\
\hline A & Pendahuluan & 4.6 & 4.6 & 4.57 & $\begin{array}{l}\text { Sangat } \\
\text { Baik }\end{array}$ \\
\hline $\mathrm{B}$ & Kegiatan Inti & 4.2 & 4.6 & 4.38 & Baik \\
\hline $\mathrm{C}$ & Penutup & 4.2 & 4.6 & 4.40 & Baik \\
\hline $\mathrm{D}$ & $\begin{array}{l}\text { Suasana } \\
\text { Kelas }\end{array}$ & 4.0 & 4.8 & 4.42 & Baik \\
\hline $\mathrm{E}$ & $\begin{array}{l}\text { Alokasi } \\
\text { Waktu }\end{array}$ & 4.0 & 4.0 & 4.00 & Baik \\
\hline \multicolumn{2}{|c|}{ Jumlah Rerata } & 4.19 & 4.51 & 4.35 & Baik \\
\hline \multicolumn{2}{|c|}{ Keterlaksanaan } & $84 \%$ & $90 \%$ & $87 \%$ & \\
\hline \multicolumn{2}{|c|}{ Reliabilitas } & \multicolumn{4}{|c|}{$96.34 \%$} \\
\hline \multirow[t]{2}{*}{ No } & \begin{tabular}{|l|} 
Aspek Yang \\
\end{tabular} & \multicolumn{4}{|c|}{ Pertemuan 3} \\
\hline & Diamati & P I & P II & Rerata & Kategori \\
\hline 1 & 2 & 3 & 4 & 5 & 6 \\
\hline A & Pendahuluan & 4.6 & 4.7 & 4.64 & $\begin{array}{l}\text { Sangat } \\
\text { Baik }\end{array}$ \\
\hline B & Kegiatan Inti & 4.4 & 4.6 & 4.52 & $\begin{array}{l}\text { Sangat } \\
\text { Baik }\end{array}$ \\
\hline $\mathrm{C}$ & Penutup & 4.2 & 4.7 & 4.42 & Baik \\
\hline $\mathrm{D}$ & $\begin{array}{l}\text { Suasana } \\
\text { Kelas }\end{array}$ & 4.5 & 4.8 & 4.67 & $\begin{array}{l}\text { Sangat } \\
\text { Baik }\end{array}$ \\
\hline $\mathrm{E}$ & $\begin{array}{l}\text { Alokasi } \\
\text { Waktu }\end{array}$ & 4.0 & 4.0 & 4.00 & Baik \\
\hline \multicolumn{2}{|c|}{ Jumlah Rerata } & 4.33 & $\begin{array}{c}4.5 \\
6\end{array}$ & 4.45 & Baik \\
\hline \multicolumn{2}{|c|}{ Keterlaksanaan } & $87 \%$ & $91 \%$ & $89 \%$ & \\
\hline & eliabilitas & \multicolumn{4}{|c|}{$97.41 \%$} \\
\hline \multirow{2}{*}{\multicolumn{2}{|c|}{$\begin{array}{c}\text { Rerata } \\
\text { Keterlaksanaan } \\
\text { Pert. 1, } 2 \text { \& } 3\end{array}$}} & 4.13 & 4.47 & 4.30 & Baik \\
\hline & & $83 \%$ & $89 \%$ & $86 \%$ & \\
\hline \multicolumn{2}{|c|}{$\begin{array}{c}\text { Reliabilitas Pert. 1, } \\
2 \text { \& } 3\end{array}$} & \multicolumn{4}{|c|}{$96.06 \%$} \\
\hline
\end{tabular}

Keterangan skala interval penilaian :

$$
\begin{array}{ll}
\mathrm{SB} & =\text { Sangat Baik }(4.50 \leq \mathrm{P} \leq 5.00) \\
\mathrm{B} & =\text { Baik }(3.50 \leq \mathrm{P} \leq 4.49) \\
\mathrm{CB} & =\text { Cukup Baik }(2.50 \leq \mathrm{P} \leq 3.49) \\
\mathrm{KB} & =\text { Kurang Baik }(1.50 \leq \mathrm{P} \leq 2.49) \\
\mathrm{TB} & =\text { Tidak Baik }(1.00 \leq \mathrm{P} \leq 1.49)
\end{array}
$$

Berdasarkan Tabel 5 di atas dapat dilihat pada pertemuan 1 keterlaksanaan pendahuluan, kegiatan inti, penutup, dan suasana kelas berkategori baik, sedangkan alokasi waktu berkategori cukup baik, hal ini disebabkan pada pertemuan 1 siswa masih belum tahu cara mengerjakan LKS dan masih dalam tahap menyesuaikan diri dengan pembelajaran yang digunakan sehingga memerlukan alokasi waktu yang cukup banyak sebagai guru untuk mengubah kebiasaan cara belajar siswa yang selalu menerima informasi dari guru, menjadi siswa aktif menemukan sendiri. Keterlaksanaan RPP pada pertemuan 2 menunjukkan bahwa keterlaksanaan pendahuluan berkategori sangat baik, hal ini disebabkan karena siswa antusias mengikuti kegiatan pembelajaran. kegiatan inti, penutup, dan suasana kelas berkategori baik. Pada pertemuan 3 keterlaksanaan RPP sudah berjalan dengan baik dan sangat baik, hal ini dikarenakan persiapan guru dalam mengantisipasi kendala-kendala yang ada sudah dipersiapkan dengan baik, selain itu juga siswa sangat antusias dan telah terbiasa dengan model pembelajaran yang digunakan.

Berdasarkan hasil pengamatan keterlaksanaan RPP pada pertemuan 1, 2 dan 3 yang meliputi pengamatan KBM pendahuluan, kegiatan inti, penutup, suasana kelas, dan alokasi waktu memiliki nilai ratarata sebesar 4,30 dengan kategori baik dan rata-rata reliabilitas instrumen keterlaksanaan RPP adalah 96,06\% artinya RPP dalam penelitian ini dapat terlaksana dengan sangat baik sehingga layak digunakan sebagai pembelajaran. Berdasarkan kriteria dari Borich, (1994), yang menyatakan bahwa suatu instrumen dikategorikan baik dan dapat digunakan untuk kegiatan pengamatan jika memiliki koefisien reliabilitas lebih besar atau sama dengan 75\%, dengan demikian instrumen pengamatan keterlaksanaan RPP yang digunakan dalam penelitian ini termasuk kategori baik dan layak digunakan sebagai lembar pengamatan. Adapun hasil dari Tabel 3 dapat divisualisasikan dalam bentuk grafik sebagai berikut:

Kriteria penilaian sebagai berikut:

$$
\begin{array}{ll}
1,00 \leq X \leq 1,49: & \begin{array}{l}
\text { berarti tidak baik (tidak } \\
\text { dilakukan sama sekali) }
\end{array} \\
1,50 \leq X \leq 2,49: & : \begin{array}{l}
\text { berarti kurang baik (dilakukan } \\
\text { tetapi tidak selesai) }
\end{array}
\end{array}
$$




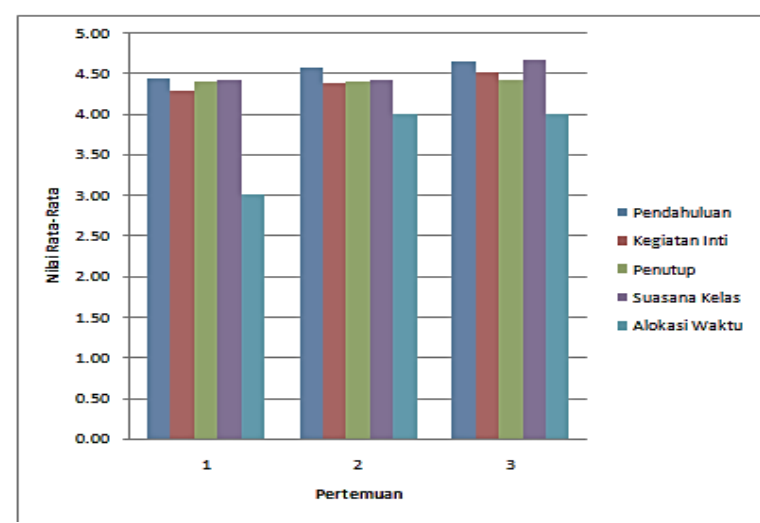

Gambar 2. Grafik Rata-Rata Keterlaksanaan RPP

Menurut Nur (2008) menyatakan bahwa salah satu faktor yang mempengaruhi kualitas pembelajaran adalah tersedianya perangkat pembelajaran yang disertai komitmen yang tinggi untuk menggunakannya dalam setiap pembelajaran. Suatu program pembelajaran akan dapat mencapai hasil seperti yang yang diharapkan apabila direncanakan dengan baik, semua komponen pengajaran harus diperankan secara optimal.

Pendapat Nur didukung oleh Sagala (2008) bahwa semua komponen pengajaran harus diperankan secara optimal guna mencapai tujuan pengajaran yang telah dirumuskan sebelum pengajaran dilaksanakan.

\section{B. Hasil Pengamatan Aktivitas Siswa}

Aktivitas siswa dalam penelitian ini merupakan rangkaian kegiatan yang dilakukan siswa dalam mengikuti pembelajaran yang diamati oleh dua orang pengamat dengan menggunakan lembar pengamatan aktivitas siswa. Hasil pengamatan aktivitas siswa pada penelitian ini secara singkat dapat dilihat pada Tabel 4

Tabel 6. Hasil Pengamatan Aktivitas Siswa

\begin{tabular}{|c|c|c|c|c|c|}
\hline \multirow{2}{*}{ No } & \multirow{2}{*}{ Aktivitas } & \multicolumn{3}{|c|}{ Aktivitas Siswa tiap RPP (\%) } & \multirow{2}{*}{$\begin{array}{l}\text { Rata- } \\
\text { Rata } \\
(\%)\end{array}$} \\
\hline & & RPP 1 & RPP 2 & RPP 3 & \\
\hline 1 & $\begin{array}{l}\text { Memperhatikan/menangga } \\
\text { pimendengar penjelasan } \\
\text { guru atau teman }\end{array}$ & 17.6 & 17.4 & 16.9 & 17.3 \\
\hline 2 & $\begin{array}{l}\text { Membaca materi ajar } \\
\text { siswaLKS }\end{array}$ & 8.4 & 8.1 & 6.1 & 7.6 \\
\hline 3 & $\begin{array}{l}\text { Menanggapi } \\
\text { masalah merumuskan } \\
\text { masalah pertanyaan }\end{array}$ & 8.4 & 8.5 & 8.6 & 8.5 \\
\hline 4 & Merumuskan hipotesis & 6.1 & 6.4 & 6.4 & 6.3 \\
\hline 5 & $\begin{array}{l}\text { Merancang dan melakukan } \\
\text { pengamatan percobaan }\end{array}$ & 17.7 & 17.8 & 18.4 & 18.0 \\
\hline 6 & $\begin{array}{l}\text { Mencatat dan menganalisis } \\
\text { hasil } \\
\text { pengamatan/percobaan }\end{array}$ & 14.6 & 14.6 & 15.9 & 15.1 \\
\hline 7 & $\begin{array}{l}\text { Mempresentasikan hasil } \\
\text { pengamatan dan berdiskusi } \\
\text { kelas }\end{array}$ & 9.7 & 9.8 & 10.6 & 10.1 \\
\hline 8 & Membuat kesimpulan & 5.8 & 6.2 & 6.2 & 6.1 \\
\hline 9 & $\begin{array}{l}\text { Bertanya pada guru atau } \\
\text { teman }\end{array}$ & 8.6 & 9.0 & 9.7 & 9.1 \\
\hline 10 & $\begin{array}{l}\text { Perilaku yang tidak relevan } \\
\text { dengan KBM }\end{array}$ & 3.0 & 2.1 & 1.0 & 2.0 \\
\hline & Jumlah & 100 & 100 & 100 & 100 \\
\hline
\end{tabular}

Tabel 6 di atas dapat divisualisasikan dalam bentuk grafik sebagai berikut:

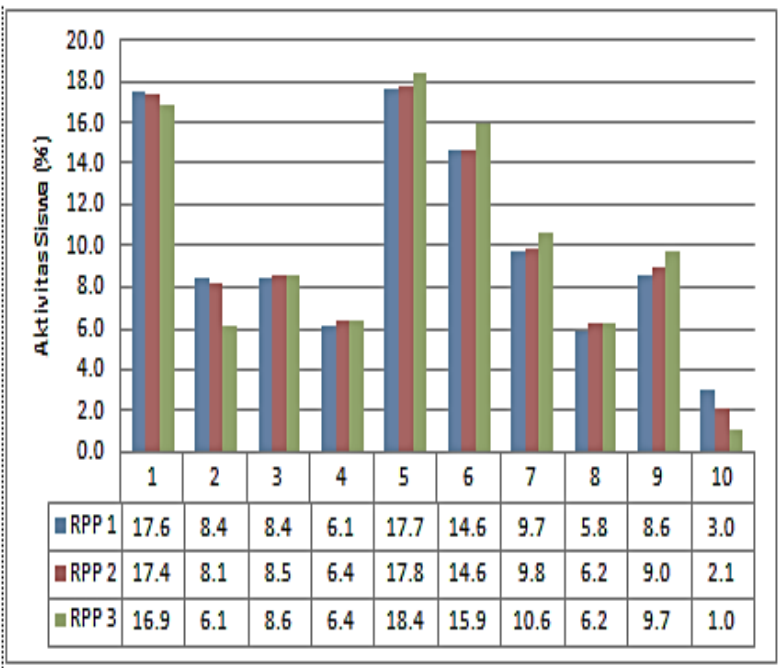

Gambar 3. Grafik Pengamatan Aktivitas Siswa

Keterangan grafik:

1. Memperhatikan/menanggapi atau mendengar penjelasan guru atau teman

2. Membaca materi ajar siswa/LKS

3. Menanggapi masalah atau merumuskan masalah/pertanyaan dalam LKS

4. Merumuskan hipotesis

5. Merancang dan melakukan pengamatan atau percobaan

6. Mencatat dan menganalisis hasil pengamatan atau percobaan

7. Mempresentasikan hasil pengamatan dan berdiskusi kelas

8. Membuat kesimpulan

9. Bertanya pada guru atau teman

10. Perilaku yang tidak relevan dengan KBM

Pertemuan pertama dalam kegiatan pembelajaran, guru masih sering memberikan penjelasan karena siswa masih sangat memerlukan pengarahan/bimbingan dalam mengerjakan LKS. Pada pertemuan kedua sampai pertemuan ketiga siswa mulai aktif bertanya pada guru, menyampaikan pendapat, dan aktif dalam diskusi kelompok maupun diskusi kelas, guru selalu memberikan umpan balik positif sehingga siswa merasa dihargai dan termotivasi dalam belajar.

Antusiasme siswa cukup tinggi dalam mengikuti proses pembelajaran karena pembelajaran model inkuiri terbimbing menggunakan LKS berorientasi keterampilan berpikir kritis merupakan hal yang baru bagi siswa, sehingga persentase aktivitas lain seperti berprilaku yang tidak relevan dengan kegiatan pembelajaran sangat sedikit dibandingkan dengan aktivitas lain. Aktivitas siswa yang paling dominan selama proses pembelajaran model inkuiri terbimbing menggunakan LKS berorientasi keterampilan berpikir kritis adalah merancang dan melakukan pengamatan/percobaan yaitu $17,7 \%$ pada pertemuan 
pertama, $17,8 \%$ pada pertemuan kedua, dan $18,4 \%$ pada pertemuan ketiga. Hal ini menunjukkan bahwa selama proses pembelajaran, siswa lebih banyak terlibat dalam keterampilan berpikir, sebagaimana teori Piaget dalam Trianto (2009) yang menyatakan bahwa salah satu implikasi penting dalam pembelajaran adalah memfokuskan pada proses berpikir anak, bukan hanya kemampuan produk saja.

Sejalan dengan hal tersebut Bruner dalam Nur (2008) menyatakan bahwa keterlibatan aktif siswa dalam eksperimen, memungkinkan siswa menemukan konsep, prinsip sendiri sehingga mereka lebih memahami apa yang ada dalam pembelajaran. Aktivitas tersebut juga menunjukkan bahwa kegiatan pembelajaran berpusat pada siswa. Pembelajaran yang demikian memungkinkan siswa secara aktif membangun pengetahuannya sendiri atau menjadikan informasi pengetahuan menjadi miliknya sendiri. Menurut Piaget dalam Nur (2008), keterlibatan siswa secara aktif dalam pembelajaran memudahkan mereka mengasimilasi dan mengakomodasi informasi baru sehingga siswa mudah memahami fakta yang ada dalam pengalaman tersebut.

Adapun reliabilitas pengamatan aktivitas siswa selama kegiatan belajar mengajar dapat dilihat dalam Tabel 7 berikut:
Tabel 7. Reliabilitas Aktivitas Siswa Selama KBM

\begin{tabular}{|c|c|c|c|c|}
\hline \multirow{3}{*}{$\begin{array}{c}\text { Pengamatan } \\
\text { terhadap } \\
\text { Siswa }\end{array}$} & \multicolumn{3}{|c|}{ Reliabilitas Tiap RPP (\%) } & \multirow{2}{*}{$\begin{array}{c}\text { Rata- } \\
\text { Rata } \\
(\%)\end{array}$} \\
\hline & RPP 1 & RPP 2 & RPP 3 & \\
\hline & 94.6 & 95.4 & 96.0 & 95.3 \\
\hline
\end{tabular}

Tabel 7 menunjukkan rata-rata reliabilitas aktivitas siswa yaitu sebesar 95,3\% yang berarti instrumen tersebut dikatakan baik dan dapat digunakan untuk mengamati aktivitas siswa. Hal ini seiring dengan pendapat Borich (1994) yang menyatakan bahwa jika persentase kesepakatan kedua pengamat dikatakan reliabel yaitu $\geq 75 \%$, maka instrumen tersebut termasuk kategori baik.

\section{Hasil Belajar}

1. Analisis hasil belajar pengetahuan

Ketuntasan hasil belajar siswa dinilai dengan melihat hasil belajar yang diperoleh dari pretest dan posttest yang dilakukan sebelum pertemuan pertama dan sesudah pertemuan ketiga. Hasil belajar siswa ditinjau dari ketuntasan hasil belajar terhadap pembelajaran yang telah dilakukan meliputi ketuntasan indikator, ketuntasan individual dan klasikal. Analisis sensitivitas dan ketuntasan indikator pada penelitian ini disajikan pada Tabel berikut:

Tabel 8. Ketuntasan indikator dan sensitivitas tes THB

\begin{tabular}{|c|c|c|c|c|c|c|c|c|c|}
\hline \multirow{2}{*}{ Indikator } & \multirow[t]{2}{*}{$\begin{array}{c}\text { No } \\
\text { Soal }\end{array}$} & \multicolumn{2}{|c|}{$\begin{array}{l}\text { Proporsi } \\
\text { Butir Soal }\end{array}$} & \multicolumn{2}{|c|}{$\begin{array}{c}\% \\
\text { Ketuntasan }\end{array}$} & \multicolumn{2}{|c|}{ Ket } & \multirow{2}{*}{$\begin{array}{c}\text { Sens } \\
\text { itivit } \\
\text { as }\end{array}$} & \multirow{2}{*}{$\begin{array}{l}\text { Kat } \\
\text { ego } \\
\text { ri }\end{array}$} \\
\hline & & U1 & U2 & $\mathbf{U 1}$ & $\mathbf{U} 2$ & U1 & $\mathbf{U} 2$ & & \\
\hline 1 & 2 & 3 & 4 & 5 & 6 & 7 & 8 & 9 & 10 \\
\hline Menjelaskan pengertian ekosistem & 1 & 0.60 & 1.00 & 60 & 100 & TT & $\mathrm{T}$ & 0.40 & $\begin{array}{l}\text { Sen } \\
\text { sitif }\end{array}$ \\
\hline $\begin{array}{l}\text { Menentukan tingkatan organisasi kehidupan dalam suatu } \\
\text { ekosistem. }\end{array}$ & 2 & 0.47 & 0.83 & 47 & 83 & TT & $\mathrm{T}$ & 0.37 & $\begin{array}{l}\text { Sen } \\
\text { sitif }\end{array}$ \\
\hline Menentukan komponen penyusun ekosistem. & 3 & 0.47 & 0.80 & 47 & 80 & TT & $\mathrm{T}$ & 0.33 & $\begin{array}{l}\text { Sen } \\
\text { sitif }\end{array}$ \\
\hline $\begin{array}{l}\text { Menentukan jenis interaksi antar komponen dalam } \\
\text { ekosistem dengan melakukan percobaan hubungan } \\
\text { komponen abiotik dengan komponen biotik. }\end{array}$ & 4 & 0.43 & 0.83 & 43 & 83 & TT & $\mathrm{T}$ & 0.40 & $\begin{array}{l}\text { Sen } \\
\text { sitif }\end{array}$ \\
\hline $\begin{array}{l}\text { Menentukan organisme yang termasuk ke dalam } \\
\text { tingkatan trofik berdasarkan aliran energi yang terjadi } \\
\text { dalam suatu ekosistem }\end{array}$ & 5 & 0.50 & 0.87 & 50 & 87 & TT & $\mathrm{T}$ & 0.37 & $\begin{array}{l}\text { Sen } \\
\text { sitif }\end{array}$ \\
\hline Menjelaskan pengertian daur biogeokimia & 6 & 0.53 & 0.89 & 53 & 89 & TT & $\mathrm{T}$ & 0.36 & $\begin{array}{l}\text { Sen } \\
\text { sitif }\end{array}$ \\
\hline $\begin{array}{l}\text { Mendeskripsikan urutan mekanisme perpindahan aliran } \\
\text { energi pada permasalahan tertentu. }\end{array}$ & 7 & 0.50 & 0.89 & 50 & 89 & TT & $\mathrm{T}$ & 0.39 & $\begin{array}{l}\text { Sen } \\
\text { sitif }\end{array}$ \\
\hline $\begin{array}{l}\text { Menganalisis hubungan aliran energi pada rantai } \\
\text { makanan dalam jaring-jaring makanan. }\end{array}$ & 8 & 0.35 & 0.80 & 35 & 80 & TT & $\mathrm{T}$ & 0.45 & $\begin{array}{l}\text { Sen } \\
\text { sitif }\end{array}$ \\
\hline $\begin{array}{l}\text { Membuat skema hubungan rantai makanan dalam jaring- } \\
\text { jaring makanan yang terjadi dalam suatu ekosistem }\end{array}$ & 9 & 0.32 & 0.78 & 32 & 78 & TT & $\mathrm{T}$ & 0.46 & $\begin{array}{l}\text { Sen } \\
\text { sitif }\end{array}$ \\
\hline $\begin{array}{l}\text { Membuat skema/daur air melalui percobaan proses } \\
\text { terbentuknya awan }\end{array}$ & 10 & 0.29 & 0.77 & 29 & 77 & TT & $\mathrm{T}$ & 0.47 & $\begin{array}{l}\text { Sen } \\
\text { sitif }\end{array}$ \\
\hline
\end{tabular}

Keterangan:

$$
\text { TT }=\text { Tidak Tuntas } \quad \mathrm{T}=\text { Tuntas } \quad \mathrm{U} 1=\text { Pre test } \quad \mathrm{U} 2=\text { Post test }
$$


Tabel 8 di atas dapat divisualisasikan dalam bentuk grafik sebagai berikut:

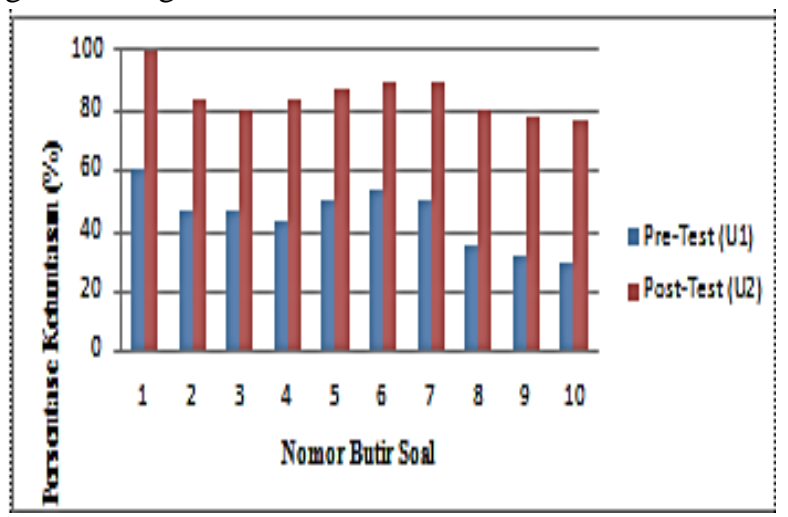

Gambar 4. Grafik Ketuntasan Indikator

Pada Tabel 8 dan Gambar Grafik 4 dapat dilihat bahwa ketuntasan tiap indikator dari pretest ke posttest mengalami peningkatan. Pada pretest ketuntasan indikator berkisar antara 29-60\%, sedangkan untuk posttest ketuntasan indikatornya berkisar antara 77 $100 \%$.

Tingginya ketuntasan indikator "menjelaskan pengertian ekosistem" yang mencapai $100 \%$ setelah siswa mengikuti pembelajaran menunjukkan bahwa semua siswa sangat antusias terhadap pembelajaran materi ekosistem sehingga seluruh siswa mengerti dan dapat mendeskripsikan pengertian ekosistem dengan baik dan benar. Rendahnya indikator "membuat skema/daur air melalui percobaan proses terbentuknya awan" yang hanya mencapai 77\% menunjukkan bahwa beberapa orang siswa masih kesulitan dalam membuat skema/daur air melalui percobaan. Hal ini disebabkan karena dalam melakukan percobaan praktikum belum sesuai dengan rancangan yang mereka buat dalam LKS sehingga menyulitkan beberapa orang siswa memahami indikator tersebut.

Secara umum tingginya ketuntasan semua indikator yang digunakan dalam pembuatan tes hasil belajar pengetahuan menunjukkan bahwa pembelajaran model inkuiri terbimbing menggunakan LKS berorientasi keterampilan berpikir kritis berhasil dalam membelajarkan materi ekosistem ini tidak lepas dari fase-fase yang menuntun siswa untuk aktif dalam pembelajaran. Hal ini sesuai dengan teori belajar menurut pandangan konstruktivisme, menyatakan bahwa anak tidak menerima begitu saja pengetahuan dari orang lain, tetapi anak secara aktif membangun pengetahuannya yang sebelumnya anak sudah mempunyai kemampuan awal. Menurut Piaget, seperti yang dikutip oleh Nur (1998), perkembangan kognitif sebagian besar bergantung pada seberapa jauh anak aktif memanipulasi dan aktif berinteraksi dengan lingkungannya. Lingkungan belajar anak sangat menentukan proses perkembangan kognitif anak. Jika lingkungan belajar maupun tempat tinggal anak merupakan lingkungan yang aktif, penuh kompetisi, sehat dalam memecahkan masalah, maka kognisi anak akan terpola untuk mampu menguasai konsep dan memecahkan suatu masalah dengan cepat.

Ketuntasan individual dan klasikal tes hasil belajar pengetahuan dapat disajikan pada Gambar Grafik 5 dan Tabel 9 berikut:

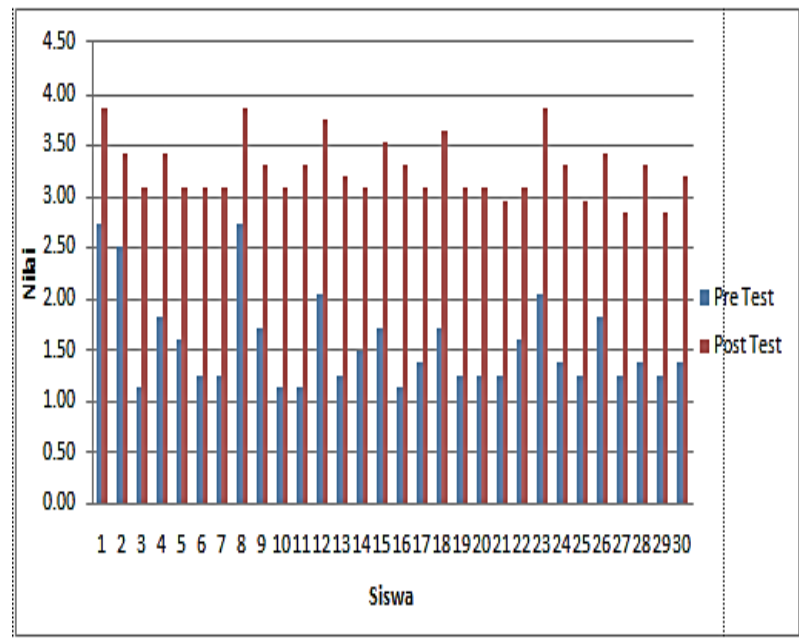

Gambar 5. Grafik Ketuntasan Individual dan Klasikal Pengetahuan

Tabel 9. Ketuntasan individual dan klasikal tes hasil belajar pengetahuan

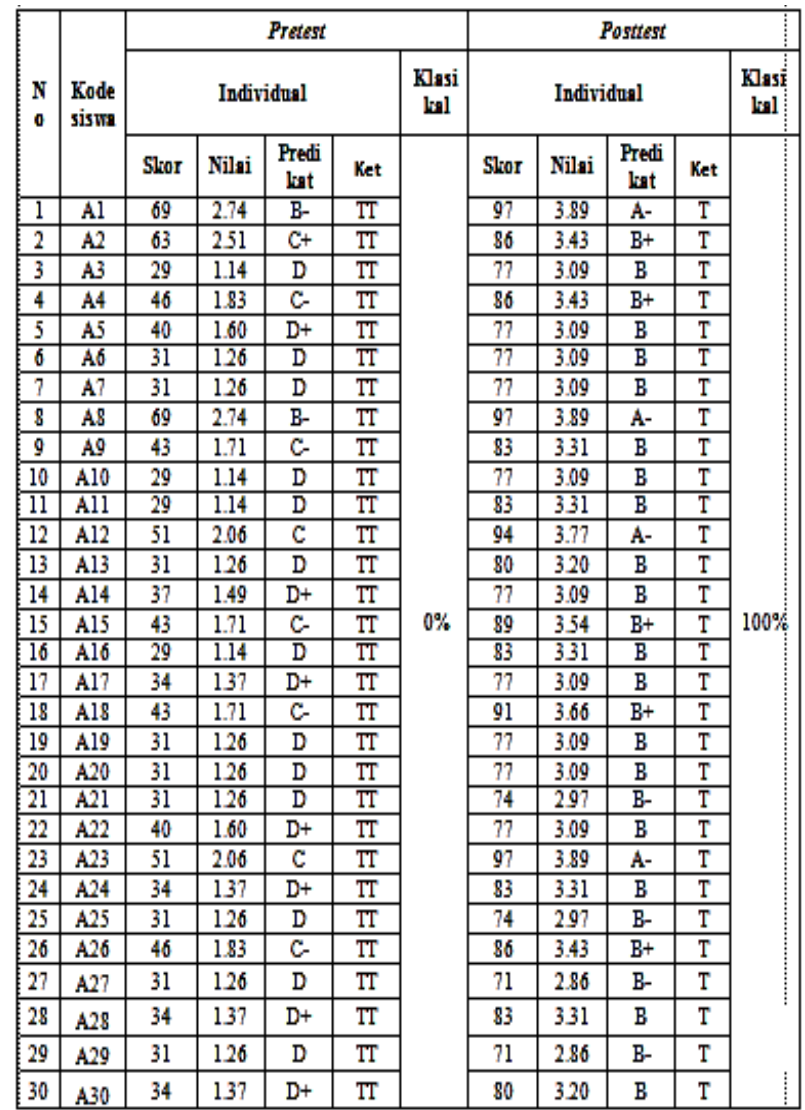


Tabel 9 dan Gambar 5 menunjukkan pada pretest tidak ada siswa yang tuntas dengan ketuntasan klasikal $0 \%$ dan pada posttest semua siswa tuntas dengan ketuntasan klasikal $100 \%$.

Hasil belajar antara pretest dan posttest menunjukkan perbedaan yang signifikan, hal ini membuktikan bahwa penelitian ini dapat meningkatkan hasil belajar siswa yang berorientasi kemampuan berpikir kritis. Pembelajaran dengan model inkuiri terbimbing menggunakan LKS berorientasi keterampilan berpikir kritis juga berarti dalam menyerap pembelajaran siswa tidak hanya melihat dan mendengar saja tetapi juga melakukan kegiatan eksperimen dan berdiskusi. Hal ini sesuai dengan teori kerucut Edgar Dale dalam Sanjaya (2009) mengatakan bahwa pembelajaran dapat terserap $10 \%$ jika diperoleh dari membaca, $20 \%$ jika dari mendengar, $30 \%$ dari melihat, $50 \%$ dari melihat dan mendengar, $70 \%$ jika dari diskusi dan $95 \%$ jika dari mengerjakan kembali.

Indeks sensitivitas butir soal merupakan ukuran seberapa baik butir soal tersebut untuk membedakan antara siswa yang telah dan yang belum mengikuti KBM. Berdasarkan Tabel 8 indeks sensitivitas butir soal rata-rata berkisar $0,33-0,47$ jauh di atas ketentuan minimal indeks sensitivitas yaitu 0,30 . Hal ini menunjukkan bahwa butir soal yang digunakan pada Tes Hasil Belajar dapat membedakan dengan sangat baik antara siswa yang belum diberikan perlakuan dan yang telah diberi perlakuan.

Sementara itu, perhitungan peningkatan (gain-score) pada tes pengetahuan dapat dilihat pada Tabel 10 .

Tabel 10. Perhitungan gain-score penilaian tes pengetahuan

\begin{tabular}{|c|c|c|c|c|c|c|c|c|c|c|c|}
\hline \multirow[b]{2}{*}{ No } & \multirow{2}{*}{$\begin{array}{l}\text { Kode } \\
\text { siswa }\end{array}$} & \multicolumn{4}{|c|}{ Pretest } & \multicolumn{4}{|c|}{ Postest } & \multirow{2}{*}{$\begin{array}{l}\text { Gain } \\
\text { Score }\end{array}$} & \multirow[b]{2}{*}{ Ket } \\
\hline & & $\begin{array}{c}\text { Jumlah } \\
\text { Jawaban }\end{array}$ & Skor & Nilai & $\begin{array}{l}\text { Predi- } \\
\text { kat }\end{array}$ & $\begin{array}{c}\text { Jumlah } \\
\text { Jawaban }\end{array}$ & Skor & Nilai & $\begin{array}{c}\text { Predi- } \\
\text { kat }\end{array}$ & & \\
\hline 1 & A1 & 24 & 69 & 2.74 & B- & 34 & 97 & 3.89 & A- & 0.91 & g-tinggi \\
\hline 2 & $\mathrm{~A} 2$ & 22 & 63 & 2.51 & $\mathrm{C}+$ & 30 & 86 & 3.43 & $\mathrm{~B}+$ & 0.62 & g-sedang \\
\hline 3 & A3 & 10 & 29 & 1.14 & $\mathrm{D}$ & 27 & 77 & 3.09 & $\mathrm{~B}$ & 0.68 & g-sedang \\
\hline 4 & A4 & 16 & 46 & 1.83 & $\mathrm{C}-$ & 30 & 86 & 3.43 & $\mathrm{~B}+$ & 0.74 & g-tinggi \\
\hline 5 & A5 & 14 & 40 & 1.60 & D+ & 27 & 77 & 3.09 & $\mathrm{~B}$ & 0.62 & g-sedang \\
\hline 6 & A6 & 11 & 31 & 1.26 & $\mathrm{D}$ & 27 & 77 & 3.09 & $\mathrm{~B}$ & 0.67 & g-sedang \\
\hline 7 & A7 & 11 & 31 & 1.26 & $\mathrm{D}$ & 27 & 77 & 3.09 & $\mathrm{~B}$ & 0.67 & g-sedang \\
\hline 8 & A8 & 24 & 69 & 2.74 & B- & 34 & 97 & 3.89 & A- & 0.91 & g-tinggi \\
\hline 9 & A9 & 15 & 43 & 1.71 & C- & 29 & 83 & 3.31 & $\mathrm{~B}$ & 0.70 & g-tinggi \\
\hline 10 & A10 & 10 & 29 & 1.14 & $\mathrm{D}$ & 27 & 77 & 3.09 & $\mathrm{~B}$ & 0.68 & g-sedang \\
\hline 11 & A11 & 10 & 29 & 1.14 & $\mathrm{D}$ & 29 & 83 & 3.31 & $\mathrm{~B}$ & 0.76 & g-tinggi \\
\hline 12 & A12 & 18 & 51 & 2.06 & $\mathrm{C}$ & 33 & 94 & 3.77 & A- & 0.88 & g-tinggi \\
\hline 13 & A13 & 11 & 31 & 1.26 & $\mathrm{D}$ & 28 & 80 & 3.20 & B & 0.71 & g-tinggi \\
\hline 14 & A14 & 13 & 37 & 1.49 & $\mathrm{D}+$ & 27 & 77 & 3.09 & $\mathrm{~B}$ & 0.64 & g-sedang \\
\hline 15 & A15 & 15 & 43 & 1.71 & C- & 31 & 89 & 3.54 & $\mathrm{~B}+$ & 0.80 & g-tinggi \\
\hline 16 & A16 & 10 & 29 & 1.14 & $\mathrm{D}$ & 29 & 83 & 3.31 & $\mathrm{~B}$ & 0.76 & g-tinggi \\
\hline 17 & A17 & 12 & 34 & 1.37 & $\mathrm{D}+$ & 27 & 77 & 3.09 & B & 0.65 & g-sedang \\
\hline 18 & A18 & 15 & 43 & 1.71 & $\mathrm{C}-$ & 32 & 91 & 3.66 & A- & 0.85 & g-tinggi \\
\hline 19 & A19 & 11 & 31 & 1.26 & $\mathrm{D}$ & 27 & 77 & 3.09 & $\mathrm{~B}$ & 0.67 & g-sedang \\
\hline 20 & A20 & 11 & 31 & 1.26 & $\mathrm{D}$ & 27 & 77 & 3.09 & $\mathrm{~B}$ & 0.67 & g-sedang \\
\hline 21 & A21 & 11 & 31 & 1.26 & $\mathrm{D}$ & 26 & 74 & 2.97 & B- & 0.63 & g-sedang \\
\hline 22 & A22 & 14 & 40 & 1.60 & D+ & 27 & 77 & 3.09 & B & 0.62 & g-sedang \\
\hline 23 & A23 & 18 & 51 & 2.06 & $\mathrm{C}$ & 34 & 97 & 3.89 & A- & 0.94 & g-tinggi \\
\hline 24 & A24 & 12 & 34 & 1.37 & $\mathrm{D}+$ & 29 & 83 & 3.31 & $\mathrm{~B}$ & 0.74 & g-tinggi \\
\hline 25 & A25 & 11 & 31 & 1.26 & $\mathrm{D}$ & 26 & 74 & 2.97 & B- & 0.63 & g-sedang \\
\hline 26 & A26 & 16 & 46 & 1.83 & $\mathrm{C}-$ & 30 & 86 & 3.43 & $\mathrm{~B}+$ & 0.74 & g-tinggi \\
\hline 27 & A27 & 11 & 31 & 1.26 & $\mathrm{D}$ & 25 & 71 & 2.86 & B- & 0.58 & g-sedang \\
\hline 28 & A28 & 12 & 34 & 1.37 & D+ & 29 & 83 & 3.31 & $\mathrm{~B}$ & 0.74 & g-tinggi \\
\hline 29 & A29 & 11 & 31 & 1.26 & $\mathrm{D}$ & 25 & 71 & 2.86 & B- & 0.58 & g-sedang \\
\hline 30 & A30 & 12 & 34 & 1.37 & $\mathrm{D}+$ & 28 & 80 & 3.20 & $\mathrm{~B}$ & 0.70 & g-sedang \\
\hline \multicolumn{3}{|c|}{ Rata-rata } & 39 & 1.57 & D+ & & 82 & 3.28 & B & 0.70 & g-tinggi \\
\hline
\end{tabular}

Berdasarkan Tabel 10 menunjukkan Gain Score pretest dan posttest rata-ratanya 0,70 (tinggi) sesuai dengan klasifikasi dari Savinainen \& Scott (2002) hal ini menunjukkan bahwa kegiatan pembelajaran model inkuiri terbimbing menggunakan LKS berorientasi keterampilan berpikir kritis efektif dapat meningkatkan hasil belajar siswa yang berorientasi pada keterampilan berpikir kritis. Indeks Gain Score yang tinggi 
menunjukkan bahwa perangkat yang digunakan dalam kegiatan pembelajaran memiliki kualifikasi valid, reliabel, dan efektif sesuai penilaian validator.

\section{Analisis hasil belajar keterampilan}

Ketuntasan hasil belajar keterampilan pada penelitian ini dapat dilihat pada Tabel 11

Tabel 11. Ketuntasan Hasil Belajar Keterampilan

\begin{tabular}{|c|c|c|c|c|c|c|c|}
\hline \multirow{2}{*}{ No. } & \multirow{2}{*}{$\begin{array}{l}\text { Kode } \\
\text { Sissm }\end{array}$} & \multicolumn{3}{|c|}{ Observasi } & \multirow{2}{*}{ Nilai } & \multirow{2}{*}{ Peredilast } & \multirow{2}{*}{ Ketuntasan } \\
\hline & & 1 & 2 & 3 & & & \\
\hline$\frac{1}{1}$ & 2 & 2 & 4 & 3 & 6 & 7 & 2 \\
\hline 1 & A1 & 3.50 & 3.50 & 3.75 & 3.58 & $\mathrm{~B}^{+}$ & Treats \\
\hline 2 & $A_{2}$ & 3.25 & 3.13 & 3.63 & 3.33 & $\mathrm{~B}+$ & Treass \\
\hline 3 & $A 3$ & 288 & 3.00 & 3.13 & 3.00 & B & Treass \\
\hline 4 & A4 & 300 & 288 & 3.25 & 3.04 & B & Treats \\
\hline 5 & AS & 300 & 300 & 3.13 & 3.04 & B & Treats \\
\hline 6 & A6 & 288 & 288 & 3.25 & 3.00 & B & Treass \\
\hline 7 & A7 & 300 & 3.13 & 3.13 & 3.08 & B & Treats \\
\hline 8 & A8 & 300 & 3.00 & 3.13 & 3.04 & B & Treass \\
\hline 9 & Ag & 288 & 288 & 3.38 & 3.04 & B & Treass \\
\hline 10 & $A 10$ & 258 & 3.00 & 3.25 & 3.04 & B & Treass \\
\hline II & A11 & 258 & 3.00 & 3.38 & 3.08 & B & Treass \\
\hline 12 & A12 & 3.00 & 3.00 & 3.13 & 3.04 & B & Treass \\
\hline 13 & A13 & 3.50 & 3.50 & 3.25 & 3.42 & $\mathrm{~B}+$ & Treass \\
\hline 14 & A.14 & 288 & 288 & 3.13 & 296 & B- & Treass \\
\hline 15 & A1S & 288 & 288 & 3.13 & 296 & B & Treas \\
\hline 16 & A15 & 3.00 & 3.00 & 3.25 & 3.08 & B & Treass \\
\hline 17 & A17 & 288 & 288 & 3.13 & 296 & B- & Treass \\
\hline 18 & A18 & 300 & 3.00 & 3.25 & 3.08 & B & Treass \\
\hline 19 & A19 & 288 & 3.00 & 3.25 & 3.04 & B & Treatas \\
\hline 20 & A20 & 288 & 288 & 3.13 & 296 & B & Treats \\
\hline 21 & A21 & 3.00 & 3.00 & 3.00 & 3.00 & B & Treass \\
\hline 22 & A.22 & 288 & 288 & 3.00 & 292 & B & Treass \\
\hline 23 & A.23 & 3.50 & 288 & 3.13 & 3.17 & B & Treass \\
\hline 24 & A.24 & 300 & 3.13 & 3.25 & 3.13 & B & Teens \\
\hline 25 & $A 25$ & 300 & 300 & 3.13 & 3.04 & B & Trouss \\
\hline 26 & A.25 & 300 & 258 & 3.25 & 3.04 & B & Treass \\
\hline 27 & 427 & 288 & 3.13 & 3.38 & 3.13 & B & Treass \\
\hline 28 & $A 28$ & 3.50 & 288 & 3.13 & 3.17 & B & Treats \\
\hline 29 & $A 29$ & 3.00 & 3.13 & 3.25 & 3.13 & B & Treass \\
\hline 30 & $A 30$ & 288 & 3.13 & 3.25 & 3.08 & B & Treass \\
\hline & 3.02 & 3.01 & 3.23 & 3.09 & B & Tmiss \\
\hline
\end{tabular}

Tabel 11 menunjukan bahwa hasil belajar keterampilan pada pembelajaran terhadap 30 orang siswa dengan skor antara 2,92-3,58 dengan predikat baik, berarti semua tuntas secara individual dengan ketuntasan klasikal $\geq 75 \%$. Penilaian keterampilan dalam penelitian ini meliputi melakukan penyelidikan terdiri dari merumuskan masalah, merumuskan hipotesis, merencanakan prosedur percobaan, melakukan pengamatan, melakukan anlisis data dan menyimpulkan. Mengomunikasikan hasil penyelidikan terdiri dari penguasaan konsep, penampilan presenter, dan tayangan presenter. Hasil belajar keterampilan pada penelitian ini dinyatakan semua tuntas secara individual dan klasikal yang berarti aspek-aspek yang dinilai terlaksana dengan baik.

\section{Analisis hasil belajar sikap}

Ketuntasan hasil belajar sikap dapat dilihat pada Tabel 12.
Tabel 12. Ketuntasan Hasil Belajar Sikap

\begin{tabular}{|c|c|c|c|c|c|c|}
\hline \multirow[b]{2}{*}{ No. } & \multirow{2}{*}{$\begin{array}{l}\text { Kode } \\
\text { Siswa } \\
\end{array}$} & \multicolumn{2}{|c|}{ Nilai Sikap } & \multirow{2}{*}{$\begin{array}{c}\text { Rata- } \\
\text { rata }\end{array}$} & \multirow{2}{*}{ Peredikat } & \multirow{2}{*}{$\begin{array}{c}\text { Ketuntasgn } \\
\text { Individu } \\
\end{array}$} \\
\hline & & Spiritual & Sosial & & & \\
\hline 1 & 2 & 3 & 4 & $s$ & $s$ & 7 \\
\hline 1 & A1 & 3.89 & 3.42 & 3.65 & B & Tuntas \\
\hline 2 & $A 2$ & 3.33 & 3.17 & 3.25 & B & Tuntss \\
\hline 3 & $\mathrm{A3}$ & 3.22 & 3.10 & 3.16 & B & Tuntss \\
\hline 4 & A4 & 3.22 & 2.75 & 2.99 & B & Tuntas \\
\hline 5 & A5 & 3.33 & 3.35 & 3.34 & B & Tuntas \\
\hline 6 & $A 6$ & 3.33 & 3.00 & 3.17 & B & Tuntas \\
\hline 7 & A7 & 3.50 & 3.23 & 3.36 & B & Tuntas \\
\hline 8 & $A B$ & 3.28 & 3.02 & 3.15 & B & Tuntas \\
\hline 9 & A9 & 3.11 & 2.71 & 2.91 & B & Tuntas \\
\hline 10 & A10 & 3.00 & 2.88 & 2.94 & B & Tuntas \\
\hline 11 & A11 & 3.00 & 3.02 & 3.01 & B & Tuntas \\
\hline 12 & A12 & 3.83 & 3.42 & 3.63 & B & Tuntas \\
\hline 13 & A13 & 3.28 & 3.13 & 3.20 & B & Tuntas \\
\hline 14 & A14 & 3.17 & 2.69 & 2.93 & B & Tuntas \\
\hline 15 & A15 & 3.22 & 2.67 & 2.94 & B & Tuntas \\
\hline 16 & A16 & 3.33 & 3.35 & 3.34 & B & Tuntas \\
\hline 17 & A17 & 3.28 & 3.00 & 3.14 & B & Tuntas \\
\hline 18 & A18 & 3.50 & 3.23 & 3.36 & B & Tuntss \\
\hline 19 & A19 & 3.28 & 2.79 & 3.03 & B & Tuntss \\
\hline 20 & A20 & 3.11 & 2.71 & 2.91 & B & Tuntas \\
\hline 21 & A21 & 3.00 & 2.88 & 2.94 & B & Tuntas \\
\hline 22 & A22 & 3.00 & 3.02 & 3.01 & B & Tuntas \\
\hline 23 & A23 & 3.28 & 2.85 & 3.07 & B & Tuntas \\
\hline 24 & A24 & 3.33 & 3.13 & 3.23 & B & Tuntss \\
\hline 25 & A25 & 3.22 & 2.75 & 2.99 & B & Tuntas \\
\hline 26 & A26 & 3.11 & 2.96 & 3.03 & B & Tuntas \\
\hline 27 & A27 & 3.22 & 2.83 & 3.03 & B & Tuntas \\
\hline 28 & $\mathrm{~A} 28$ & 3.11 & 2.96 & 3.03 & B & Tuntas \\
\hline 29 & A29 & 3.17 & 2.81 & 2.99 & B & Tuntas \\
\hline 30 & A30 & 3.28 & 2.85 & 3.07 & B & Tuntas \\
\hline \multicolumn{2}{|c|}{ Rata-Rista } & 3.26 & 2.99 & 3.13 & B & Tuntes \\
\hline
\end{tabular}

Hasil belajar sikap spiritual dan sosial pada penelitian ini dinyatakan semua tuntas secara individual dan klasikal karena indikator karakter sikap dilatihkan dan dibiasakan dalam pembelajaran, sebagai contoh ikut menjaga kebersihan kelas sebagai wujud pengamalan agama yang dianut. Hal tersebut sesuai dengan pendapat Mulyasa (2013) pembentukan sikap atau karakter memang tidak bisa sim salabim atau terbentuk dalam waktu singkat, tetapi indikator perilaku dapat dideteksi secara dini oleh guru. Pembelajaran menggunakan model inkuiri terbimbing juga mendukung pembiasaan nilai-nilai karakter sikap tersebut, sebagai contoh adalah melakukan kegiatan secara disiplin dalam belajar dan bekerja, baik secara individu maupun kelompok.

\section{Analisis Keterampilan Berpikir Kritis}

Keterampilan berpikir kritis diukur dengan menggunakan tes keterampilan berpikir kritis. Tes diberikan berupa 5 (lima) butir soal uraian, tes diberikan bersamaan dengan tes hasil belajar sebanyak dua kali yaitu pretest dan posttest. Ketuntasan keterampilan berpikir kritis dapat dilihat pada Tabel 13.

Tabel 13. Ketuntasan Individual, Klasikal, dan Gainscore Keterampilan Berpikir Kritis 


\begin{tabular}{|c|c|c|c|c|c|c|c|c|c|c|c|c|c|}
\hline & \multirow{3}{*}{$\begin{array}{l}\text { Kode } \\
\text { sisक8 }\end{array}$} & \multicolumn{5}{|c|}{ Pretest } & \multicolumn{5}{|c|}{ Postist } & \multirow{3}{*}{$\begin{array}{l}\text { Gain } \\
\text { Score }\end{array}$} & \multirow{3}{*}{ Ket } \\
\hline & & \multicolumn{4}{|c|}{ Indiridual } & $\begin{array}{c}\text { Klasj- } \\
\text { kal }\end{array}$ & \multicolumn{4}{|c|}{ Indiridual } & Klasj- & & \\
\hline & & Skor & Nillei & $\begin{array}{r}\text { Predi- } \\
\text { lat }\end{array}$ & Ket & \multirow{32}{*}{$0 \%$} & Skor & Nillai & $\begin{array}{l}\text { Predi- } \\
\text { kat }\end{array}$ & Ket & \multirow{32}{*}{$100 \%$} & & \\
\hline 1 & $\mathrm{Al}$ & 45 & 1.80 & $c$ & TI & & 95 & 3.80 & A- & $\mathrm{T}$ & & 0.91 & gtin \\
\hline 2 & $\mathrm{~A}_{2}$ & 40 & 1.00 & $\mathrm{D}+$ & IT & & 90 & 3.60 & $\mathrm{~B}+$ & $\mathrm{I}$ & & 0.83 & getin \\
\hline 3 & $\mathrm{~A}^{3}$ & 30 & 120 & D & TT & & 75 & 3.00 & B & $\mathrm{T}$ & & 0.64 & $5 \operatorname{sed}$ \\
\hline 4 & $\mathrm{~A} 4$ & 35 & 1.40 & $\mathrm{D}+$ & TT & & 85 & 3.40 & $\mathrm{~B}+$ & $\mathrm{I}$ & & 0.77 & \\
\hline 5 & A5 & 30 & 120 & $\mathrm{D}$ & $\pi$ & & 80 & 320 & $B$ & $T$ & & 0.71 & gtin \\
\hline 6 & A 6 & 30 & 120 & $\bar{D}$ & TI & & 75 & 3.00 & $B$ & $\mathrm{I}$ & & 0.64 & 58 \\
\hline$?$ & A? & 30 & 120 & $D$ & $\pi$ & & 85 & 3.40 & $\mathrm{BH}^{+}$ & $\mathrm{T}$ & & 0.79 & \\
\hline 8 & As & 45 & 1.80 & C & TI & & 95 & 3.80 & A- & I & & 9! & \\
\hline 9 & A9 & 25 & 1.00 & $D$ & TI & & 85 & 3.40 & $\mathrm{B+}$ & $\mathrm{T}$ & & 80 & \\
\hline 10 & All & 30 & 120 & $D$ & TT & & 75 & 3.00 & $B$ & $\mathrm{~T}$ & & 0.64 & sised \\
\hline 11 & All & 25 & 1.00 & $\mathrm{D}$ & $\pi$ & & 85 & 3.40 & $\mathrm{Bt}$ & $T$ & & 0.80 & gatin \\
\hline 12 & Al2 & 40 & 1.60 & D+ & $\pi$ & & 85 & 3.40 & $\mathrm{~B}+$ & T & & 0.75 & gatin \\
\hline 13 & $\mathrm{Al3}$ & 25 & 1.00 & $\mathrm{D}$ & TI & & 75 & 3.00 & $B$ & $\mathrm{~T}$ & & 0.67 & ased \\
\hline 14 & Al4 & 30 & 120 & $D$ & TT & & 85 & 3.40 & $\mathrm{~B}+$ & $\mathrm{T}$ & & 0.79 & ating \\
\hline 15 & Al5 & 40 & 1.60 & $\mathrm{D}+$ & TT & & 80 & 320 & $B$ & $\mathrm{~T}$ & & \begin{tabular}{|l|}
0.67 \\
\end{tabular} & gradi \\
\hline 16 & A16 & 30 & 120 & $\mathrm{D}$ & $\pi$ & & 75 & 3.00 & B & $T$ & & 0.64 & sast \\
\hline 17 & Al? & 30 & 120 & $\mathrm{D}$ & TT & & 85 & 3.40 & $\mathrm{~B}^{+}$ & $\mathrm{T}$ & & 0.79 & gatin \\
\hline 18 & Als & 35 & 1.40 & $\overline{D+}$ & TI & & 80 & 320 & B & $\mathrm{T}$ & & 0.69 & $g$ \\
\hline 19 & Al9 & 25 & 1.00 & $D$ & TI & & 75 & 3.00 & $B$ & $\mathrm{~T}$ & & 0.67 & grada \\
\hline 20 & A20 & 35 & 1.40 & $\mathrm{D}+$ & TT & & 85 & 3.40 & $\mathrm{~B}+$ & $\mathrm{T}$ & & 0.77 & gating \\
\hline 21 & A21 & 30 & 120 & $\mathrm{D}$ & $\pi$ & & 80 & 320 & $B$ & $\mathrm{~T}$ & & 0.71 & gati \\
\hline 22 & A22 & 30 & 120 & D & TT & & 75 & 3.00 & B & T & & 0.64 & s $5 \mathrm{ed}$ \\
\hline 23 & $\mathrm{~A} 23$ & 45 & 1.80 & 6 & TI & & 85 & 3.40 & $\mathrm{~B}+$ & $\mathrm{I}$ & & 0.73 & gtin \\
\hline 24 & A24 & 25 & 1.00 & $D$ & TT & & 85 & 3.40 & $\mathrm{~B}^{+}$ & $\mathrm{T}$ & & 0.80 & stin \\
\hline 25 & A25 & 30 & 120 & $D$ & TT & & 70 & 2.80 & B- & $\mathrm{I}$ & & 0.57 & sosd \\
\hline 26 & A26 & 35 & 1.40 & $\mathrm{D}+$ & TI & & 85 & 3.40 & $\mathrm{~B}+^{+}$ & $\mathrm{I}$ & & 0.77 & atin \\
\hline 27 & A27 & 25 & 1.00 & $D$ & IT & & 70 & 2.80 & B- & $\mathrm{I}$ & & 0.60 & grasd \\
\hline 28 & A28 & 30 & 120 & $\mathrm{D}$ & TT & & 70 & 2.80 & B- & $\mathrm{T}$ & & 0.57 & grasd \\
\hline 29 & A29 & 25 & 1.00 & $D$ & IT & & 70 & 2.80 & B- & $\mathrm{T}$ & & 0.60 & godad \\
\hline 30 & A30 & 35 & 1.40 & $\mathrm{D}+$ & IT & & 80 & 320 & $B$ & $\mathrm{I}$ & & 0.69 & gsedan \\
\hline & a-rata & 32 & 1.29 & D & $\mathrm{TT}$ & & 81 & 3,23 & B & $\mathrm{T}$ & & 0.71 & g-ting \\
\hline
\end{tabular}

Ketuntasan hasil tes keterampilan berpikir kritis sesuai Tabel 13 di atas diketahui bahwa sebelum pembelajaran dilakukan secara individual dan klasikal semua siswa tidak tuntas dengan nilai pretest individual berkisar antara 1,00 (D) - 1,80 (C-) dan klasikal 0\%, sedangkan setelah pembelajaran secara klasikal $100 \%$ siswa tuntas dengan nilai posttest individual berkisar antara 2,80 (B-) - 3,80 (A-).

Berdasarkan Tabel 13 di atas diketahui bahwa skor peningkatan (gain-score) yang diperoleh setiap siswa tergolong tinggi, yaitu berkisar antara 0,57 - 0,91 dengan rata-rata 0.71 . Hal tersebut menyatakan bahwa terjadi peningkatan nilai siswa dengan nilai rata-rata pretest 1,29 dengan predikat D mengalami peningkatan nilai rata-rata posttest 3,23 dengan predikat $\mathrm{B}$.

Sensitivitas soal tes berpikir kritis menggunakan LKS berorientasi keterampilan berpikir kritis menunjukkan bahwa sensitivitas butir soal keterampilan berpikir kritis dari soal nomor 1 sampai 5 memiliki sensitivitas lebih dari 0,30 termasuk kategori sensitif / peka terhadap efek pembelajaran. Hasil analisis sensitivitas soal berpikir kritis dapat dilihat pada Tabel 14.
Tabel 14. Hasil Analisis Sensitivitas Soal Berpikir

Kritis

\begin{tabular}{|c|c|c|c|c|c|c|}
\hline \multirow[b]{2}{*}{$\begin{array}{l}\text { Butir } \\
\text { Soal }\end{array}$} & \multicolumn{2}{|c|}{$\begin{array}{c}\text { Jumlah Skor } \\
\text { Siswa }\end{array}$} & \multirow[b]{2}{*}{$\begin{array}{l}\text { Skor } \\
\text { Max }\end{array}$} & \multirow[b]{2}{*}{$\begin{array}{l}\text { Skor } \\
\text { Min }\end{array}$} & \multirow[b]{2}{*}{$\begin{array}{l}\text { Sensit } \\
\text { ivitas }\end{array}$} & \multirow[b]{2}{*}{$\begin{array}{l}\text { Keteran } \\
\text { gan }\end{array}$} \\
\hline & $\begin{array}{l}\text { pretes } \\
(\Sigma \mathrm{U} 21)\end{array}$ & $\begin{array}{r}\text { post tes } \\
(\Sigma \mathrm{U} 12)\end{array}$ & & & & \\
\hline 1 & 52 & 109 & 4 & 0 & 0.48 & Sensitif \\
\hline 2 & 42 & 99 & 4 & 0 & 0.48 & Sensitif \\
\hline 3 & 34 & 88 & 4 & 0 & 0.45 & Sensitif \\
\hline 4 & 33 & 89 & 4 & 0 & 0.47 & Sensitif \\
\hline 5 & 32 & 99 & 4 & 0 & 0.56 & Sensitif \\
\hline
\end{tabular}

Hasil pencapaian siswa dalam tes keterampilan berpikir kritis seperti yang ditunjukkan pada Tabel 12 menunjukkan bahwa pelaksanaan pembelajaran dengan model inkuiri terbimbing menggunakan LKS berorientasi keterampilan berpikir kritis tidak hanya meningkatakan penguasaan konsep ekosistem, tetapi juga telah meningkatkan keterampilan berpikir kritis siswa. Hal ini menunjukkan bahwa tahapan-tahapan dalan model inkuiri terbimbing tidak hanya meningkatkan penguasaan konsep tetapi juga telah memberikan kesempatan kepada siswa untuk melatihkan keterampilan berpikir kritis siswa. Pada tiap-tiap tahap model inkuiri terbimbing, siswa "dipaksa" berpikir karena melakukan kegiatan merumuskan masalah berarti siswa berpikir untuk merumuskan masalah dalam bentuk pertanyaan, melakukan kegiatan merumuskan hipotesis berarti siswa berpikir untuk merumuskan hipotesis, melakukan kegiatan merancang dan melakukan percobaan berarti siswa berpikir untuk merancang dan melakukan percobaan, melakukan kegiatan mengumpulkan dan menganalisis data berarti siswa berpikir untuk mengumpulkan dan menganalisis data, melakukan kegiatan membuat kesimpulan berarti siswa berpikir untuk membuat kesimpulan sehingga dengan menggunakan LKS keterampilan berpikir kritis siswa sengaja dilatih berpikir.

Menurut Carin (1993) seseorang didalam berinkuiri dituntut memiliki kemampuan yaitu: pengelompokan, menciptakan model, merumuskan hipotesis, mengindentifikasi variabel, observasi, pengambilan data, menganalisis dan menyimpulkan.

Pentinganya pemberdayaan berpikir kritis dalam pembelajaran juga ditekankan oleh Depdikbud bahwa salah satu keterampilan hidup yang perlu dikembangkan melalui proses pendidikan adalah keterampilan berpikir kritis. Kemampuan berpikir kritis siswa akan mengalami peningkatan seiring dengan strategi pembelajaran yang harus digunakan, oleh karena itu pembelajaran harus memberdayakan kemampuan berpikir kritis siswa (Ibrahim dan Nur, 2000) 


\section{E. Hasil Angket Respon Siswa}

Angket respon siswa digunakan untuk mengetahui respon, minat, pendapat dan penilaian siswa terhadap pelaksanaan kegiatan belajar mengajar. Angket respon siswa diberikan kepada siswa setelah pembelajaran selesai dilaksanakan. Data yang diperoleh dapat divisualisasikan dalam bentuk grafik sebagai berikut:

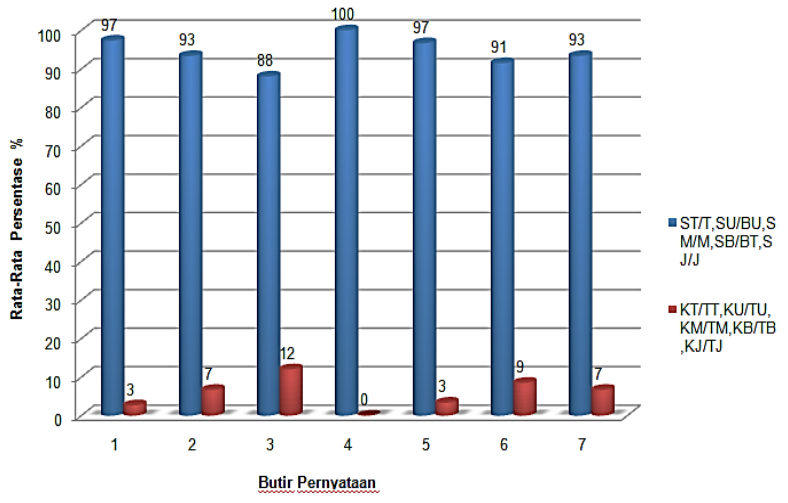

Gambar 6. Grafik Angket Respon Siswa

Keterangan:

\begin{tabular}{|c|c|c|c|}
\hline $\begin{array}{r}\text { : Sar } \\
\text { Tert }\end{array}$ & & $\begin{array}{l}\mathrm{gg} \\
\mathrm{ik}\end{array}$ & $\begin{array}{l}\text { ak } \\
\text { rik }\end{array}$ \\
\hline $\begin{array}{r}\mathrm{U}: \mathrm{Sa} \\
\mathrm{Bu}\end{array}$ & BU: Baru & $\begin{array}{r}\mathrm{KU}: \mathrm{K} \\
\mathrm{Ba}\end{array}$ & $\begin{array}{r}\mathrm{TU} \\
\mathrm{Ba}\end{array}$ \\
\hline $\mathrm{Muc}$ & M: Mudah & $\begin{array}{l}\text { rang } \\
\text { ah }\end{array}$ & \\
\hline B. Ber & B:Beminat & nat & $\begin{array}{r}\text { TB: T } \\
\text { Berr }\end{array}$ \\
\hline $\begin{array}{c}\mathrm{J}: \text { Sangat } \\
\text { jelas }\end{array}$ & $\mathrm{J}$ : Jelas & $\begin{array}{l}\text { KJ: Kuran } \\
\text { Jelas }\end{array}$ & $\begin{array}{l}\text { TJ: Tidak } \\
\text { Jelas }\end{array}$ \\
\hline
\end{tabular}

Berdasarkan data menunjukkan bahwa respon siswa terhadap ketertarikan komponen materi/isi pelajaran, bahan ajar (media pembelajaran), lembar kegiatan siswa (LKS), cara guru mengajar dengan persentase rata-rata untuk semua komponen pernyataan respon pertama adalah $97 \%$ sangat tertarik/tertarik dan $3 \%$ kurang tertarik/tidak tertarik. Keterbaruan komponen materi/isi pelajaran, lembar kegiatan siswa (LKS), suasana belajar, dan cara guru mengajar dengan persentase rata-rata untuk semua komponen pernyataan respon kedua adalah $93 \%$ sangat baru/baru dan $7 \%$ kurang baru/tidak baru. Keterbacaan komponen bahasa dalam buku, materi/isi buku, contoh-contoh soal, LKS, cara guru mengajar dengan persentase rata-rata untuk semua komponen pernyataan respon ketiga adalah $88 \%$ sangat mudah/mudah dan $12 \%$ kurang mudah/tidak mudah.

Respon siswa terhadap minat jika pokok bahasan selanjutnya menggunakan pembelajaran seperti ini dan jika pelajaran lain menggunakan pembelajaran ini dengan persentase rata-rata $100 \%$ sangat berminat/berminat. Respon siswa terhadap penjelasan guru saat KBM dan bimbingan guru pada saat berdiskusi atau melakukan percobaan dengan persentase rata-rata untuk pertanyaan respon kelima adalah $97 \%$ sangat jelas/jelas dan 3\% kurang jelas/tidak jelas. Respon siswa tentang keterampilan berpikir kritis dengan persentase rata-rata semua komponen adalah 91\% sangat mudah/mudah dan $9 \%$ kurang mudah/tidak mudah. Sedangkan respon siswa terhadap soal/tes hasil belajar dengan persentase rata-rata $93 \%$ sangat mudah/mudah dan $7 \%$ kurang mudah/tidak mudah.

Berdasarkan hasil analisis data respon siswa yang telah dikemukakan di atas dapat disimpulkan bahwa respon siswa terhadap pembelajaran model inkuiri terbimbing menggunakan LKS berorientasi keterampilan berpikir kritis bernilai mayoritas baik dan positif. Hal ini sesuai dengan pemikiran Duron, R. (2006) yang menyatakan bahwa peran aktif siswa dapat membuat proses pembelajaran lebih menyenangkan untuk guru dan siswa, dan yang paling penting peran aktif siswa dapat menyebabkan siswa untuk berpikir kritis

\section{F. Hambatan Selama Kegiatan Belajar Mengajar}

Hambatan yang ditemukan selama proses kegitan belajar mengajar pada penelitian ini adalah umumnya siswa masih belum tahu cara mengerjakan LKS berorientasi keterampilan berpikir kritis meskipun sudah disediakan contohnya. Hal ini disebabkan siswa belum pernah melakukan pembelajaran dengan menggunakan LKS tersebut, solusinya adalah guru membimbing siswa untuk mengerjakan LKS tersebut. Hal ini memerlukan perubahan kebiasaan cara belajar siswa yang biasa menerima informasi dari guru, menjadi siswa aktif menemukan sehingga perlu alokasi waktu yang lebih banyak. Selain itu kendala siswa masih belum terbiasa melakukan keterampilan berpikir kritis pada pertemuan pertama memaksa guru perlu membimbing siswa untuk melatih keterampilan berpikir kritis secara bertahap. Hal ini sejalan dengan teori Vygotsky yang menyatakan anak belajar atau mengerjakan tugas yang berada di zone of proximal development artinya, tugas-tugas seseorang anak yang tidak dapat melakukan sendiri namun dapat melakukannya dengan bantuan teman sebaya atau orang dewasa yang lebih kompeten. Vygotsky juga menyatakan dalam pengajaran menekankan scaffolding yang berarti memberikan kepada anak sejumlah besar bantuan selama tahap-tahap awal pembelajaran, kemudian mengurangi bantuan tersebut dan memberikan kesempatan kepada anak tersebut untuk mengambil alih tanggung jawab yang semakin besar segera setelah anak dapat melakukannya (Slavin, 2011).

Pada pertemuan kedua pemakaian media papan tulis belum optimal dan siswa serentak bila menjawab pertanyaan guru. Solusinya lebih dioptimalkan dalam pemakaian media papan tulis misal dalam menuliskan contoh rantai makanan dan jaring-jaring makanan, guru 
perlu memberi penjelasan apabila menjawab pertanyaan dengan angkat tangan dulu. Pada pengamatan lingkungan ekosistem sekolah, masih ada siswa yang bermain-main sehingga menghambat kegiatan tersebut solusinya guru perlu memperingatkan siswa sehingga kegiatan praktikum dapat berjalan dengan baik.

Pada pertemuan ketiga perlunya pemantapan siswa terhadap konsep-konsep daur biogeokimia solusinya guru perlu memberi tugas mengenai materi daur biogeokimia. Selain itu kendala yang lain yaitu keterbatasan alat dan bahan di laboratorium sekolah dan alih fungsi laboratorium sekolah menjadi tempat penyimpanan barang menyebabkan kegiatan praktikum menjadi terhambat dan tidak dapat dilaksanakan di laboratorium. Solusinya guru menyiapkan alat dan bahan serta menugasi siswa untuk membawa alat dan bahan yang bisa mereka bawa untuk kegiatan praktikum yang dilakukan di kelas. Sejalan dengan kegiatan praktikum tersebut Bruner menemukan bahwa guru perlu mendorong anak untuk mendapatkan pengalaman dan melakukan eksperimen yang memungkinkan mereka menemukan prinsip-prinsip bagi diri mereka sendiri (Ibrahim, 2002)

\section{KESIMPULAN}

\section{A. Simpulan}

Berdasarkan hasil penelitian maka disimpulkan bahwa pembelajaran model inkuiri terbimbing menggunakan LKS berorientasi keterampilan berpikir kritis dapat meningkatkan hasil belajar dan keterampilan berpikir kritis siswa SMA pada materi ekosistem.

\section{B. Saran}

Berdasarkan hasil penelitian penerapan pembelajaran yang telah dilakukan, peneliti memberikan saran sebagai berikut:

1. Pada pembelajaran model inkuiri terbimbing menggunakan LKS berorientasi keterampilan berpikir kritis disarankan agar guru dapat mengubah kebiasaan mengajar yang umumnya sebagai pemberi informasi menjadi fasilitator, motivator dan membimbing siswa dalam belajar dan melatih keterampilan berpikir kritis siswa secara bertahap serta menggunakan waktu yang seefektif mungkin.

2. Berdasarkan hasil penelitian diketahui bahwa, terdapat perbedaan rata-rata pretest dan posttest yang signifikan dan peningkatan gain score meningkat tinggi, sehingga pembelajaran model inkuiri terbimbing menggunakan LKS berorientasi keterampilan berpikir kritis pada materi ekosistem disarankan pada KBM menggunakan perangkat pembelajaran tersebut karena dapat meningkatkan hasil belajar dan keterampilan berpikir kritis siswa.

3. Diharapkan ada penelitian selanjutnya dengan model inkuiri terbimbing menggunakan LKS berorientasi keterampilan berpikir kritis yang diajarkan lebih intensif untuk melatih keterampilan berikir kritis dan meningkatkan hasil belajar siswa.

\section{REFERENSI}

Borich, G. D. (1994). Observation Skill for Effective Teaching. New York: Macmilan publishing Company.

Carin, A.A. (1993). Teaching Science Through Discovery. New York: Macmillan Publishing Company

Depdikbud. (2013). Permendikbud RI No. 66 tahun 2013 Tentang Standar Penilaian Pendidikan Dasar dan Menengah. Jakarta: Depdikbud

Depdikbud. (2013). Permendikbud RI No. 81A Lampiran IV tahun 2013 Tentang Implementasi Kurikulum Pedoman Umum Pembelajaran. Jakarta: Depdikbud

Dick, W and Carey, L. (1990). The Systematic Of Instructional Design $3^{\text {rd }}$ Edition. Melbourne: Merril Publishing Company.

Duron, R. (2006). "Critical Thinking Framework For Any Discipline". International Journal of Teaching and Learning in Higher Education. Vol.17 No.2, pp 160-166

Fisher A. (2009). Berpikir Kritis: Sebuah Pengantar. Jakarta: Erlangga

Gronlund, N. E. (1982). Contructing Achievement Tes, Third Edition, Englewood Clif London: Prentice-Hall Inc.

Hake, Richard R. (1999). Analyzing Change/Gain Score. Dept. Of Physics, Indiana University 24245 Hatteras Street, Woodland Hills, CA, 91367 USA.

Ibrahim, M. (2005). Assesmen Berkelanjutan. Surabaya: Unesa University Press.

Kardi, S. (2013). Model Pembelajaran Langsung Inkuiri Sains Teknologi dan Masyarakat. Surabaya: Universitas Negeri Surabaya

Kasnan, N. (2001). "Peningkatan Keterampilan Proses Melalui Pembelajaran Kooperatif dengan Metode Penugasan Kelompok, Presentasi, dan Pameran dalam Mata Pelajaran Biologi." Jurnal Pendidikan Genteng Kali (Buletin Pendidikan Jawa Timur). Volume 3 No. 8 hal 10-11. 
Khabibah, S. (2006). "Pengembangan Model Pembelajaran Matematika dengan Soal Terbuka untuk Meningkatkan Kreativitas Siswa Sekolah Dasar". (Disertase tidak dipublikasikan). Pascasarjana Universitas Negeri Surabaya.

Marzano, Robert J (1992). A different Kind of Classroom: Teaching Science for All Children. Massachusetts. Allyn and Bacon.

Mulyasa, E. (2013). Pengembangan dan Implementasi Kurikulum 2013. Bandung: PT. Remaja Rosdakarya.

Nur, M. (1995). "Pengembangan Model PBM IPA Berorientasi PKP untuk meningkatkan Daya Nalar Siswa dalam rangka Menyongsong Masyarakat Iptek pada Pembangunan Jangka Panjang Tahap Kedua" Artikel Hibah Bersaing II/2 Perguruan Tinggi Tahun Anggaran 1994/1995.

Nur, M. (1998). Teori Pembelajaran Kognitif. Surabaya: Unesa University Press.

Nur, M. (2008). Model Pembelajaran Berdasarkan Masalah. Surabaya: Unesa University Press.

Sagala, Syaiful. (2008). Konsep dan Makna Pembelajaran. Bandung: CV ALFABETA

Sanjaya, Wina, (2009). Strategi Pembelajaran Berorientasi Standar Proses Pendidikan. Cetakan ke 6. Jakarta: Kencana Perdana Media Group.
Savinainen, A. and Scott. P. 2002. "The Force Concept Inventory: A Tool for Monitoring Student Learning”. Physic Education Journal. Vol. 37 No.1, pp: 45-52

Slavin, R. E. (1994). Educational Psycology: Theory and Practice. Fort Edition. Boston: Allyn and Bacon Publishers.

Slavin, R. E. (2011a). Psikologi Pendidikan Teori dan Praktik Edisi kesembilan, Jilid 1. Jakarta: PT. Indeks.

Slavin, R. E. (2011b). Psikologi Pendidikan Teori dan Praktik Edisi kesembilan, Jilid 2. Jakarta: PT. Indeks

Trianto. (2007). Model-Model Pembelajaran Inovatif Berorientasi Konstruktivistik. Jakarta : Prestasi Pustaka.

Trianto. (2009). Mendesain Model Pembelajaran Inovatif Progresif. Jakarta: Kenaba Perdana Media Group

Tuckman, B. E. (1978). Conducting Educational Research. New York: Harcourt Brace Jovanavich Publisher.

Watkins, Marley W \& Pacheco, Miriam. (2001). "Interobserver Agreement in Behavioral Research: Importance and Calculation." Journal of Behavioral Education. Vol 10 No.4.pp 205-212. 